\title{
Fungal Secretome Database: Integrated platform for annotation of fungal secretomes
}

\author{
Jaeyoung Choi ${ }^{1,2,3}$, Jongsun Park ${ }^{1,2,3,4}$, Donghan Kim ${ }^{1,2,3}$, Kyongyong Jung 1,2,3 Seogchan Kang ${ }^{6}$, \\ Yong-Hwan Lee $1,2,3,4,5^{*}$
}

\begin{abstract}
Background: Fungi secrete various proteins that have diverse functions. Prediction of secretory proteins using only one program is unsatisfactory. To enhance prediction accuracy, we constructed Fungal Secretome Database (FSD).

Description: A three-layer hierarchical identification rule based on nine prediction programs was used to identify putative secretory proteins in 158 fungal/oomycete genomes (208,883 proteins, $15.21 \%$ of the total proteome). The presence of putative effectors containing known host targeting signals such as RXLX [EDQ] and RXLR was investigated, presenting the degree of bias along with the species. The FSD's user-friendly interface provides summaries of prediction results and diverse web-based analysis functions through Favorite, a personalized repository.

Conclusions: The FSD can serve as an integrated platform supporting researches on secretory proteins in the fungal kingdom. All data and functions described in this study can be accessed on the FSD web site at http://fsd.snu.ac.kr/.
\end{abstract}

\section{Background}

The "secretome" refers to the collection of proteins that contain a signal peptide and are processed via the endoplasmic reticulum and Golgi apparatus before secretion [1]. In organisms from bacteria to humans, secretory proteins are common and perform diverse functions. These functions include immune system [2], roles as neurotransmitters in the nervous system [3], roles as hormones/pheromones [4], acquisition of nutrients [5-7], building and remodeling of cell walls [8], signaling and environmental sensing [9], and competition with other organisms [10-13]. Some secretory proteins in pathogens function as effectors that manipulate and/or destroy host cells with special signatures. In Plasmodium and Phytophthora species, effectors carry the RXLX [EDQ] or RXLR motifs as host targeting signals [11-13].

With the aid of advanced genome sequencing technologies [14], the rapid increase of sequenced fungal genomes offers many opportunities to study the function and evolution of secretory proteins at the genome level $[15,16]$. The Comparative Fungal Genomics

\footnotetext{
* Correspondence: yonglee@snu.ac.kr
'Fungal Bioinformatics Laboratory, Seoul National University, Seoul 151-921,

*Correspondence: yonglee@snu.ac.kr
'Fungal Bioinformatics Laboratory, Seoul National University, Seoul 151-921, Korea
}

(c) 2010 Choi et al; licensee BioMed Central Ltd. This is an Open Access article distributed under the terms of the Creative Commons Attribution License (http://creativecommons.org/licenses/by/2.0), which permits unrestricted use, distribution, and reproduction in any medium, provided the original work is properly cited. archives 235 genomes from 120 fungal/oomycete species. The accurate prediction of secretory proteins in sequenced genomes is the key to realizing such opportunities.

The widely used SignalP 3.0 program [17] detected $89.81 \%$ of the 2,512 experimentally verified sequences in SPdb [18], a database containing proteins with signal peptides. To improve the accuracy of prediction, we built a hierarchical identification pipeline based on nine prediction programs (Table 1). Through this pipeline, putative secretory proteins, including pathogen effectors, encoded by 158 fungal and oomycete genomes were identified. The Fungal Secretome Database (FSD; http:// fsd.snu.ac.kr/) was established to support not only the archiving of fungal secretory proteins but also the management and use of the resulting data. The FSD also has a user-friendly web interface and offers several data analysis functions via Favorite, a personalized data repository implemented in the CFGP (http://cfgp.snu.ac.kr/)[16].

\section{Construction and content}

Evaluation of the pipeline for predicting secretory proteins To evaluate the capabilities of four programs SignalP 3.0 [17], SigCleave [19], SigPred [20], and RPSP [21] for 
Table 1 List of prediction programs used in FSD

\begin{tabular}{|c|c|c|}
\hline Prediction Program & Description & Ref \\
\hline SignalP 3.0 & A program to predict whether a protein has the signal peptidase site I or not & [17] \\
\hline SigCleave & A program to predict whether a protein has signal peptides or not & [19] \\
\hline SigPred & A program to predict whether a protein has signal peptides or not & [20] \\
\hline RPSP & A program to predict whether a protein has signal peptides or not & [21] \\
\hline TMHMM 2.0C & A program to predict whether a protein has trans-membrane helix(es) or not & [26] \\
\hline TargetP 1.1b & A program to predict a site where a protein probably resides & [23] \\
\hline PSort II & A program to predict a site where a protein probably resides & [22] \\
\hline SecretomeP $1.0 f$ & A program to predict whether a protein is secreted by non-classical pathways or not & [25] \\
\hline predictNLS & A program to predict whether a protein has nuclear localization signal or not & [28] \\
\hline
\end{tabular}

predicting signal peptides, we analyzed the secretory proteins collected in SPdb [18]. SignalP 3.0 identified $89.81 \%$ of 2,512 proteins; while adding the other three programs, in combination, $87.50 \%$ of the proteins, which were not predicted by SignalP 3.0, were identified. The remaining proteins ( $1.31 \%$ of 2,512 proteins) were investigated by using two programs that predicted subcellular localization: PSort II [22] and TargetP 1.1b [23]. We found that $34.38 \%$ of the proteins were predicted to be extracellular proteins, increasing the coverage to $99.16 \%$. For the 1,093 characterized fungal/oomycete secretory proteins (Table 2), the combinatory pipeline raised the prediction coverage from $75.30 \%$ to $84.17 \%$ in comparison to SignalP 3.0. In addition, $98.14 \%$ of 24,921 experimentally unverified sequences in the SPdb were predicted as secretory proteins by the pipeline, while SignalP 3.0 caught $80.22 \%$ of them as positive. To assess robustness of the pipeline with non-secretory proteins, we prepared yeast proteins localized in cytosol, endoplasmic reticulum, nucleus, or mitochondrion [24]. When the 1,955 proteins were subjected to the FSD pipeline and SignalP 3.0, the numbers of false positives were almost same ( 84 and 82 , respectively). Together, these results suggest that this ensemble approach could

Table 2 List of references and annotation results of characterized fungal secretory proteins

\begin{tabular}{|c|c|c|c|c|c|c|}
\hline Title & $\begin{array}{c}\text { Total } \\
\text { Identified } \\
\text { Proteins }\end{array}$ & $\begin{array}{c}\text { Class } \\
\text { SP }\end{array}$ & $\begin{array}{c}\text { Class } \\
\mathrm{SP}^{3}\end{array}$ & $\begin{array}{c}\text { Class } \\
\text { SL }\end{array}$ & $\begin{array}{l}\text { Putative } \\
\text { Secretome }\end{array}$ & Ref \\
\hline $\begin{array}{l}\text { Crucial Role of Antioxidant Proteins and Hydrolytic Enzymes in Pathogenicity of } \\
\text { Penicillium expansum: Analysis Based on Proteomics Approach (Secretory) }\end{array}$ & 21 & 5 & 1 & 0 & 6 & $\overline{[43]}$ \\
\hline $\begin{array}{l}\text { Crucial Role of Antioxidant Proteins and Hydrolytic Enzymes in Pathogenicity of } \\
\text { Penicillium expansum: Analysis Based on Proteomics Approach (Non-secretory) }\end{array}$ & 21 & 1 & 2 & 0 & 3 & [43] \\
\hline $\begin{array}{l}\text { The Phanerochaete chrysosporium secretome: Database predictions and initial mass } \\
\text { spectrometry peptide identifications in cellulose-grown medium }\end{array}$ & 49 & 25 & 5 & 0 & 30 & {$[4$} \\
\hline $\begin{array}{l}\text { An analysis of the Candida albicans genome database for soluble secreted proteins } \\
\text { using computer-based prediction algorithms (Secretory) }\end{array}$ & 46 & 28 & 19 & 2 & 49 & {$[45$} \\
\hline $\begin{array}{l}\text { An analysis of the Candida albicans genome database for soluble secreted proteins } \\
\text { using computer-based prediction algorithms (Non-secretory) }\end{array}$ & 45 & 0 & 5 & 1 & 6 & [45] \\
\hline The secretome of the maize pathogen Ustilago maydis (Without known functions) & 386 & 352 & 18 & 10 & 380 & [46] \\
\hline The secretome of the maize pathogen Ustilago maydis (With known functions) & 168 & 147 & 15 & 5 & 167 & {$[46$} \\
\hline A Catalogue of the Effector Secretome of Plant Pathogenic Oomycetes & 25 & 22 & 1 & 0 & 23 & {$[11$} \\
\hline $\begin{array}{l}\text { Fungal degradation of wood: initial proteomic analysis of extra cellular proteins of } \\
\text { Phanerochaete chrysosporium grown on oak substrate }\end{array}$ & 11 & 8 & 0 & 0 & 8 & {$[47$} \\
\hline $\begin{array}{l}\text { Comparative proteomics of extracellular proteins in vitro and in planta from the } \\
\text { pathogenic fungus Fusarium graminearum }\end{array}$ & 120 & 63 & 8 & 0 & 71 & {$[4$} \\
\hline $\begin{array}{l}\text { Expression analysis of extracellular proteins from Phanerochaete chrysosporium grown on } \\
\text { different liquid and solid substrates }\end{array}$ & 27 & 16 & 4 & 0 & 20 & [49] \\
\hline $\begin{array}{l}\text { Dandruff-associated Malassezia genomes reveal convergent and divergent virulence } \\
\text { traits shared with plant and human fungal pathogens }\end{array}$ & 34 & 28 & 0 & 0 & 28 & {$[5$} \\
\hline $\begin{array}{l}\text { Adaptive Evolution Has Targeted the C-Terminal Domain of the RXLR Effectors of Plant } \\
\text { Pathogenic Oomycetes }\end{array}$ & 79 & 79 & 0 & 0 & 79 & [41] \\
\hline $\begin{array}{l}\text { Genome, transcriptome, and secretome analysis of wood decay fungus Postia placenta } \\
\text { supports unique mechanisms of lignocellulose conversion. }\end{array}$ & 47 & 29 & 3 & 1 & 33 & {$[5$} \\
\hline Host-Microbe Interactions: Shaping the Evolution of the Plant Immune Response & 14 & 12 & 0 & 1 & 13 & [52] \\
\hline Total & 1,093 & 815 & 81 & 20 & 916 & - \\
\hline
\end{tabular}


compensate for some of the weaknesses of individual programs, resulting in more robust predictions. Additionally, SecretomeP 1.0f [25], which can predict nonclassical secretory proteins, was integrated into the FSD.

The FSD contains an identification pipeline that sequentially analyzes proteomes of interest using i) SignalP 3.0; ii) a combination of SigCleave, SigPred, and RPSP to screen those proteins not considered positive by SignalP 3.0; and iii) PSort II and TargetP $1.1 \mathrm{~b}$ to analyze the negatives from the previous step. Additionally, SecretomeP 1.0f was integrated to provide information related to non-classical secretory proteins. To eliminate potential false positives, we filtered proteins that i) contain more than one transmembrane helix predicted by TMHMM 2.0c [26] and/or ii) the endoplasmic reticulum retention signal ([KRHQSA]- [DENQ]-E-L; classified as false-positive; Figure 1A) [27]. In addition, iii) nuclear proteins predicted by both predictNLS [28] and PSort II [22] and iv) mitochondrial proteins predicted by PSort II [22] as well as TargetP 1.1b [23] were eliminated because two subcellular localizations are not related to secretory proteins.

Following analysis via the pipeline, the resulting putative secretory proteins after removing potential false positives are divided into four classes: i) SP contains all proteins predicted by SignalP 3.0; ii) $\mathrm{SP}^{3}$ contains the proteins predicted by SigPred, SigCleave, or RPSP but not by SignalP 3.0; iii) SL contains the proteins predicted by PSort II and/or TargetP 1.1b but not by the first two steps; and iv) NS contains the proteins predicted by SecretomeP 1.0f but not by SignalP 3.0 (Figure 1A; Table 3).

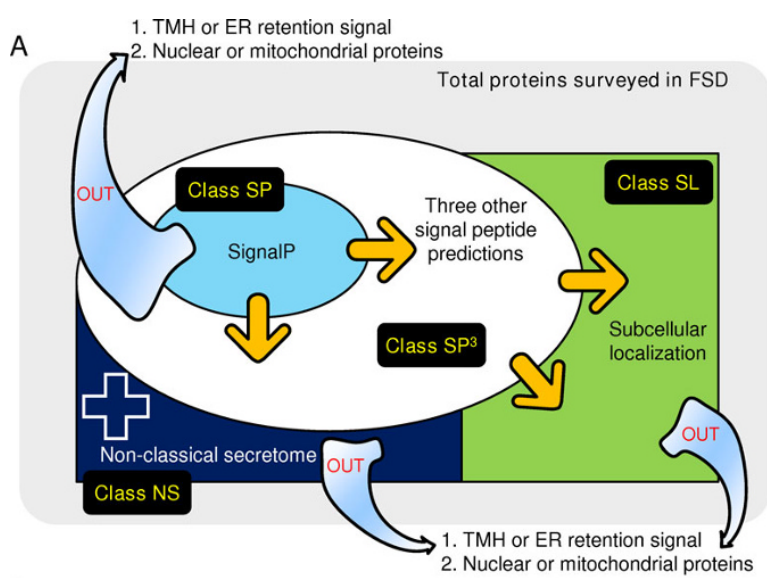

B

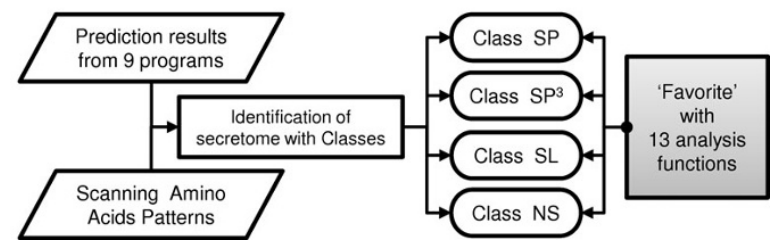

Figure 1 FSD class definitions and the FSD pipeline. (A) Definitions of four FSD classes. The gray round rectangle indicates the total set of proteins, and the light blue arrows going outside the rectangle show the filtering out processes of the pipeline. The black rectangles show the names of the classes, the yellow arrows indicate expansion of the putative secretome boundary, and the white-bordered blue cross indicates additional information on the putative secretome. (B) Structure of the FSD pipeline. The two parallelograms are input data for the FSD pipeline. The rectangle in the middle indicates the process for identifying putative secretory proteins. The round rectangles indicate the four FSD classes. The gray square on the right represents the thirteen different analysis functions in Favorite.

Table 3 Class definitions used in FSD

\begin{tabular}{ll}
\hline Class & Description* \\
\hline Class SP & Proteins which are predicted by SignalP 3.0 \\
Class SP & Proteins which are predicted by SigPred, SigCleave, or RPSP \\
Class SL & Proteins which are predicted by PSort II or TargetP 1.1b, but are not predicted by SignalP 3.0, SigPred, SigCleave, RPSP, or SecretomeP 1.0f \\
Class NS & Proteins which are predicted by SecretomeP 1.0f, but are not predicted by SignalP 3.0, SigPred, SigCleave, or RPSP
\end{tabular}

* Proteins as follows were removed from all four classes described in this table: proteins which i) contain more than one trans-membrane helixes, ii) have ER retention signals, iii) predicted as mitochondrial proteins by PSort II and TargetP $1.1 \mathrm{~b}$, and iv) predicted as nuclear proteins by TargetP $1.1 \mathrm{~b}$ and predictNLS. 
Table 4 List and distribution of secretion-associated proteins of the fungal genomes belonging to the subphylum Pezizomycotina archived in FSD

\begin{tabular}{|c|c|c|c|c|c|c|c|}
\hline Species & Size (Mb) & \# of ORFs & Class SP & Class $\mathrm{SP}^{3}$ & Class SL & Putative Secretome & Ref \\
\hline \multicolumn{8}{|l|}{$\overline{\text { Fungi (Kingdom) }}{ }^{\mathrm{a}}$} \\
\hline \multicolumn{8}{|l|}{ Ascomycota (Phylum) } \\
\hline \multicolumn{8}{|l|}{ Pezizomycotina (Subphylum) } \\
\hline Aspergillus clavatus & 27.9 & 9,121 & 754 & 732 & 81 & 1,567 & {$[53,54]$} \\
\hline Aspergillus flavus & 36.8 & 12,604 & 1,200 & 990 & 142 & 2,332 & {$[55]$} \\
\hline Aspergillus fumigatus A1163 & 29.2 & 9,929 & 807 & 878 & 67 & 1,752 & [54] \\
\hline Aspergillus fumigatus AF293 & 29.4 & 9,887 & 781 & 909 & 84 & 1,774 & {$[56]$} \\
\hline Aspergillus nidulans & 30.1 & 10,568 & 922 & 877 & 96 & 1,895 & {$[57]$} \\
\hline Aspergillus niger ATCC1015 & 37.2 & 11,200 & 860 & 883 & 88 & 1,831 & $\mathrm{~N}$ \\
\hline Aspergillus niger CBS513.88 & 34.0 & 14,086 & 1,142 & 1,320 & 154 & 2,616 & [58] \\
\hline Aspergillus oryzae & 37.1 & 12,063 & 1,060 & 1,064 & 145 & 2,269 & [59] \\
\hline Aspergillus terreus & 29.3 & 10,406 & 934 & 916 & 81 & 1,931 & [53] \\
\hline Botrytis cinerea & 42.7 & 16,448 & 1,163 & 1,287 & 182 & 2,632 & N \\
\hline Chaetomium globosum $^{\mathrm{b}}$ & 34.9 & 11,124 & 1,121 & 923 & 99 & 2,143 & N \\
\hline Coccidioides immitis H538.4 & 27.7 & 10,663 & 548 & 957 & 80 & 1,585 & N \\
\hline Coccidioides immitis RMSCC 2394 & 28.8 & 10,408 & 575 & 920 & 66 & 1,561 & N \\
\hline Coccidioides immitis RMSCC 3703 & 27.6 & 10,465 & 539 & 892 & 65 & 1,496 & N \\
\hline Coccidioides immitis RS & 28.9 & 10,457 & 476 & 855 & 102 & 1,433 & [60] \\
\hline Coccidioides posadasii RMSCC 3488 & 28.1 & 9,964 & 546 & 838 & 95 & 1,479 & N \\
\hline Coccidioides posadasii Silveira & 27.5 & 10,125 & 558 & 869 & 91 & 1,518 & $\mathrm{~N}$ \\
\hline Cochliobolus heterostrophus C5 & 34.9 & 9,633 & 932 & 725 & 83 & 1,740 & N \\
\hline Cryphonectria parasitica & 43.9 & 11,184 & 1,040 & 951 & 93 & 2,084 & $\mathrm{~N}$ \\
\hline Fusarium graminearum GZ3639 c & 15.1 & 6,694 & 373 & 386 & 47 & 806 & [61] \\
\hline Fusarium graminearum MIPS & 36.1 & 13,920 & 1,370 & 1,072 & 118 & 2,560 & $\mathrm{~N}$ \\
\hline Fusarium graminearum $\mathrm{PH}-1$ & 36.6 & 13,339 & 1,282 & 1,004 & 118 & 2,404 & [61] \\
\hline Fusarium oxysporum & 61.4 & 17,608 & 1,613 & 1,297 & 147 & 3,057 & N \\
\hline Fusarium solani & 51.3 & 15,707 & 1,381 & 1,242 & 155 & 2,778 & [62] \\
\hline Fusarium verticillioides & 41.9 & 14,199 & 1,347 & 1,071 & 116 & 2,534 & N \\
\hline Histoplasma capsulatum G186AR & 29.9 & 7,454 & 357 & 578 & 96 & 1,031 & N \\
\hline Histoplasma capsulatum G217B & 41.3 & 8,038 & 393 & 583 & 103 & 1,079 & N \\
\hline Histoplasma capsulatum $\mathrm{H} 143$ & 39.0 & 9,547 & 468 & 842 & 87 & 1,397 & $\mathrm{~N}$ \\
\hline Histoplasma capsulatum H88 & 37.9 & 9,445 & 492 & 832 & 99 & 1,423 & N \\
\hline Histoplasma capsulatum Nam1 & 33.0 & 9,349 & 398 & 736 & 79 & 1,213 & [60] \\
\hline Magnaporthe oryzae & 41.7 & 11,069 & 1,573 & 833 & 64 & 2,470 & [63] \\
\hline Microsporum canis & 23.3 & 8,777 & 564 & 702 & 88 & 1,354 & $\mathrm{~N}$ \\
\hline Microsporum gypseum & 23.3 & 8,876 & 629 & 669 & 52 & 1,350 & $\mathrm{~N}$ \\
\hline Mycosphaerella fijiensis & 73.4 & 10,327 & 770 & 778 & 81 & 1,629 & N \\
\hline Mycosphaerella graminicola & 41.9 & 11,395 & 979 & 913 & 81 & 1,973 & N \\
\hline Neosartorya fischerib & 32.6 & 10,403 & 959 & 818 & 84 & 1,861 & [54] \\
\hline Neurospora crassa & 39.2 & 9,842 & 817 & 788 & 61 & 1,666 & [64] \\
\hline Neurospora crassa MIPS & 34.2 & 9,572 & 788 & 749 & 78 & 1,615 & N \\
\hline Neurospora discretadiscrete & 37.3 & 9,948 & 823 & 800 & 88 & 1,711 & $\mathrm{~N}$ \\
\hline Neurospora tetrasperma & 37.8 & 10,640 & 849 & 895 & 73 & 1,817 & N \\
\hline Paracoccidioides brasiliensis Pb01 & 33.0 & 9,136 & 402 & 808 & 71 & 1,281 & $\mathrm{~N}$ \\
\hline Paracoccidioides brasiliensis Pb03 & 29.1 & 9,264 & 470 & 823 & 92 & 1,385 & N \\
\hline Paracoccidioides brasiliensis Pb18 & 30.0 & 8,741 & 425 & 743 & 55 & 1,223 & $\mathrm{~N}$ \\
\hline Penicillium chrysogenum & 32.2 & 12,791 & 947 & 1,008 & 127 & 2,082 & [65] \\
\hline Penicillium marneffei & 28.6 & 10,638 & 713 & 792 & 109 & 1,614 & N \\
\hline Podospora anserina & 35.7 & 10,596 & 1,127 & 893 & 124 & 2,144 & [66] \\
\hline Pyrenophora tritici-repentis & 38.0 & 12,169 & 1,228 & 912 & 123 & 2,263 & $\mathrm{~N}$ \\
\hline
\end{tabular}


Table 4: List and distribution of secretion-associated proteins of the fungal genomes belonging to the subphylum Pezizomycotina archived in FSD (Continued)

\begin{tabular}{|c|c|c|c|c|c|c|c|}
\hline Sclerotinia sclerotiorum & 38.3 & 14,522 & 971 & 1,109 & 147 & 2,227 & $N$ \\
\hline Sporotrichum thermophile & 38.7 & 8,806 & 697 & 658 & 66 & 1,421 & N \\
\hline Stagonospora nodorum & 37.2 & 15,983 & 1,511 & 1,309 & 142 & 2,962 & [67] \\
\hline Talaromyces stipitatus & 35.7 & 13,252 & 748 & 1,116 & 114 & 1,978 & N \\
\hline Thielavia terrestris & 37.0 & 9,815 & 877 & 855 & 67 & 1,799 & N \\
\hline Trichoderma atroviride & 36.1 & 11,100 & 907 & 935 & 86 & 1,928 & N \\
\hline Trichoderma reesei & 33.5 & 9,129 & 738 & 766 & 70 & 1,574 & [68] \\
\hline Trichoderma virens GV29-8 & 38.8 & 11,643 & 933 & 1,009 & 93 & 2,035 & $\mathrm{~N}$ \\
\hline Trichophyton equinum & 24.2 & 8,576 & 571 & 699 & 69 & 1,339 & $\mathrm{~N}$ \\
\hline Uncinocarpus reesii & 22.3 & 7,798 & 485 & 626 & 64 & 1,175 & [60] \\
\hline Verticillium albo-atrum VaMs. 102 & 32.9 & 10,239 & 1,074 & 815 & 73 & 1,962 & $\mathrm{~N}$ \\
\hline Verticillium dahliae VdLs. 17 & 33.9 & 10,575 & 1,157 & 861 & 77 & 2,095 & N \\
\hline Total & $2,059.4$ & 641,257 & 50,164 & 52,111 & 5,578 & 107,853 & - \\
\hline
\end{tabular}

a Taxonomy based on [69]

${ }^{b}$ Insufficient exon/intron information

c Incomplete coverage of genome information

\section{System structure of the FSD}

To improve the expandability and flexibility of the FSD, we adopted a three-layer structure (i.e., data warehouse, analysis pipeline, and user interface) in its design. The data warehouse was established using the standardized genome warehouse managed by the CFGP (http://cfgp. snu.ac.kr/)[16] that has been used in various bioinformatics systems [15,29-35]. The pipeline layer was built with a series of Perl programs.

In addition to the prediction programs described above, ChloroP 1.1 as well as hydropathy plots [36] were included in the FSD to provide additional information on secretory proteins. Whenever new fungal genomes become available, the automated pipeline classifies them based on the predictions of nine programs, thus keeping the FSD current (Figure 1B).

MySQL 5.0.67 and PHP 5.2.9 were used to maintain database and to develop web-based user interfaces that present complex information intuitively. Web pages were serviced through Apache 2.2.11. Favorite, a personal data repository used in the CFGP (http://cfgp.snu.ac. $\mathrm{kr} /$ )[16], was integrated to provide thirteen functions for further analyses.

\section{Utility and Discussion Discussion \\ Secretory proteins in 158 fungal/oomycete genomes}

To survey the genome-wide distribution of secretory proteins in fungi and oomycetes, we used the pipeline to analyze all predicted proteins encoded by 158 fungal/ oomycete genomes. Of the $1,373,444$ open reading frames (ORFs) analyzed, 92,926 (6.77\%), 103,224 $(7.52 \%)$, and $12,733(0.93 \%)$ proteins belonged to classes $\mathrm{SP}, \mathrm{SP}^{3}$, and SL, respectively (Table 4,5 , and 6 ). In total, 208,883 ORFs (15.21\%) were denoted putative secretory proteins. The proteins belonging to class NS were not included in the putative secretome because they represented more than $40 \%$ of whole proteome.

To determine the phylum-level distribution of classes $\mathrm{SP}, \mathrm{SP}^{3}$, and $\mathrm{SL}$ within fungi, we investigated the proportions of the three classes among subphyla (Figure 2). Class $\mathrm{SP}^{3}$ was the largest, class SP was a little smaller, and the class SL was much smaller; this was consistent over every subphylum. Only in Plasmodium species, oomycetes, and the kingdom Metazoa class SP was dominant. Class SL did not exceeded $2.10 \%$ of the whole genome, except in Plasmodium species (4.52\%). Plasmodium species also showed the lowest variance among the three classes, which may reflect signal peptide-independent types of secretory proteins such as vacuolar transport signals (VTSs) [12]. These results may be partially affected by the composition of the training data for each prediction program and inherent features of each algorithm.

The phylum Basidiomycota had a larger proportion of secretory proteins (17.90\%) than other fungal taxonomy such as the subphylum Mucoromycotina (11.99\%) and the phyla Ascomycota (12.87\%) and Microsporidia (15.10\%). Within the phylum Ascomycota, the subphylum Pezizomycotina showed a higher portion of class SP $(7.82 \%)$ than the subphyla Saccharomycotina and Taphrinomycotina ( $4.57 \%$ and $3.74 \%$, respectively). When considered that subphylum Pezizomycotina contains many pathogenic fungi (47 of 59) compared with subphylum Saccharomycotina (11 of 65), the abundance of secretory proteins in the subphylum Pezizomycotina suggests that pathogens may have larger secretome than saprophytes in general. In fact, Magnaporthe oryzae and Neurospora crassa, a closely related pair of pathogen and non-pathogen supported by 
Table 5 List and distribution of secretion-associated proteins of the fungal genomes belonging to the subphylum Saccharomycotina and Taphrinomycotina archived in FSD

\begin{tabular}{|c|c|c|c|c|c|c|c|}
\hline Species & Size (Mb) & $\#$ of ORFs & Class SP & Class $\mathrm{SP}^{3}$ & Class SL & Putative Secretome & Ref \\
\hline \multicolumn{8}{|l|}{$\overline{\text { Fungi (Kingdom) }}{ }^{\mathrm{a}}$} \\
\hline \multicolumn{8}{|l|}{ Ascomycota (Phylum) } \\
\hline \multicolumn{8}{|l|}{ Saccharomycotina (Subphylum) } \\
\hline Candida albicans SC5314 & 14.3 & 6,185 & 321 & 405 & 87 & 813 & {$[70,71]$} \\
\hline Candida albicans WO-1 & 14.5 & 6,160 & 310 & 385 & 78 & 773 & {$[72]$} \\
\hline Candida dubliniensis $^{\mathrm{b}}$ & 14.5 & 6,027 & 308 & 340 & 71 & 719 & N \\
\hline Candida glabrata CBS138 & 12.3 & 5,165 & 231 & 290 & 49 & 570 & [73] \\
\hline Candida guilliermondii & 10.6 & 5,920 & 279 & 400 & 63 & 742 & [72] \\
\hline Candida lusitaniae & 12.1 & 5,941 & 310 & 482 & 50 & 842 & {$[72]$} \\
\hline Candida parapsilosis & 13.1 & 5,733 & 308 & 321 & 83 & 712 & {$[72]$} \\
\hline Candida tropicalis & 14.6 & 6,258 & 360 & 373 & 76 & 809 & {$[72,74]$} \\
\hline Debaryomyces hansenii & 12.2 & 6,354 & 254 & 357 & 74 & 685 & [73] \\
\hline Eremothecium gossypii & 8.8 & 4,717 & 204 & 333 & 35 & 572 & {$[75]$} \\
\hline Kluyveromyces lactis & 10.7 & 5,327 & 248 & 304 & 60 & 612 & [73] \\
\hline Kluyveromyces polysporus & 14.7 & 5,367 & 219 & 276 & 58 & 553 & {$[76]$} \\
\hline Kluyveromyces waltii & 10.9 & 4,935 & 187 & 280 & 41 & 508 & {$[77]$} \\
\hline Lodderomyces elongisporus & 15.5 & 5,802 & 253 & 351 & 50 & 654 & [72] \\
\hline Pichia stipitis & 15.4 & 5,839 & 263 & 374 & 58 & 695 & [78] \\
\hline Saccharomyces bayanus 623-6C YM4911 & 11.9 & 4,966 & 200 & 275 & 44 & 519 & {$[79]$} \\
\hline Saccharomyces bayanus MCYC 623 & 11.5 & 9,385 & 663 & 767 & 141 & 1571 & {$[80]$} \\
\hline Saccharomyces castellii & 11.4 & 4,677 & 177 & 240 & 46 & 463 & [79] \\
\hline Saccharomyces cerevisiae 273614N & 12.5 & 5,354 & 223 & 261 & 51 & 535 & [81] \\
\hline Saccharomyces cerevisiae 322134 S & 12.5 & 5,382 & 224 & 290 & 53 & 567 & {$[81]$} \\
\hline Saccharomyces cerevisiae 378604X & 12.5 & 5,400 & 232 & 267 & 53 & 552 & {$[81]$} \\
\hline Saccharomyces cerevisiae AWRI1631 & 11.2 & 5,451 & 220 & 364 & 63 & 647 & N \\
\hline Saccharomyces cerevisiae BC187 & 12.5 & 5,332 & 226 & 263 & 47 & 536 & {$[81]$} \\
\hline Saccharomyces cerevisiae DBVPG1 106 & 12.5 & 5,318 & 225 & 253 & 52 & 530 & {$[81]$} \\
\hline Saccharomyces cerevisiae DBVPG1373 & 12.4 & 5,349 & 229 & 260 & 48 & 537 & {$[81]$} \\
\hline Saccharomyces cerevisiae DBVPG1788 & 12.4 & 5,347 & 227 & 263 & 46 & 536 & {$[81]$} \\
\hline Saccharomyces cerevisiae DBVPG1853 & 12.5 & 5,359 & 224 & 265 & 51 & 540 & {$[81]$} \\
\hline Saccharomyces cerevisiae DBVPG6040 & 12.6 & 5,364 & 221 & 271 & 50 & 542 & {$[81]$} \\
\hline Saccharomyces cerevisiae DBVPG6044 & 12.5 & 5,890 & 224 & 268 & 48 & 540 & {$[81]$} \\
\hline Saccharomyces cerevisiae DBVPG6765 & 12.2 & 5,377 & 230 & 263 & 48 & 541 & {$[81]$} \\
\hline Saccharomyces cerevisiae K11 & 12.5 & 5,375 & 228 & 270 & 52 & 550 & [81] \\
\hline Saccharomyces cerevisiae L_1374 & 12.4 & 5,346 & 225 & 264 & 55 & 544 & {$[81]$} \\
\hline Saccharomyces cerevisiae L_1528 & 12.4 & 5,346 & 227 & 258 & 48 & 533 & [81] \\
\hline Saccharomyces cerevisiae M22 & 10.8 & 6,755 & 249 & 399 & 62 & 710 & [82] \\
\hline Saccharomyces cerevisiae NCYC110 & 12.5 & 5,408 & 226 & 264 & 57 & 547 & {$[81]$} \\
\hline Saccharomyces cerevisiae NCYC361 & 12.6 & 5,360 & 228 & 261 & 49 & 538 & {$[81]$} \\
\hline Saccharomyces cerevisiae RM11-1a & 11.7 & 5,696 & 264 & 283 & 63 & 610 & N \\
\hline Saccharomyces cerevisiae S288C & 12.2 & 6,692 & 394 & 425 & 99 & 918 & [83] \\
\hline Saccharomyces cerevisiae SK1 & 12.4 & 5,433 & 233 & 269 & 55 & 557 & {$[81]$} \\
\hline Saccharomyces cerevisiae UWOPS03_461_4 & 12.6 & 5,329 & 218 & 268 & 51 & 537 & {$[81]$} \\
\hline Saccharomyces cerevisiae UWOPS05_217_3 & 12.6 & 5,350 & 217 & 264 & 47 & 528 & {$[81]$} \\
\hline Saccharomyces cerevisiae UWOPS05_227_2 & 12.6 & 5,334 & 220 & 266 & 51 & 537 & {$[81]$} \\
\hline Saccharomyces cerevisiae UWOPS83_787_3 & 12.6 & 5,392 & 225 & 269 & 51 & 545 & {$[81]$} \\
\hline Saccharomyces cerevisiae UWOPS87_2421 & 12.6 & 5,368 & 226 & 266 & 56 & 548 & [81] \\
\hline Saccharomyces cerevisiae W303 & 12.4 & 5,467 & 237 & 271 & 52 & 560 & {$[81]$} \\
\hline Saccharomyces cerevisiae Y12 & 12.6 & 5,370 & 223 & 268 & 57 & 548 & [81] \\
\hline Saccharomyces cerevisiae Y55 & 12.3 & 5,415 & 239 & 262 & 60 & 561 & {$[81]$} \\
\hline
\end{tabular}


Table 5: List and distribution of secretion-associated proteins of the fungal genomes belonging to the subphylum Saccharomycotina and Taphrinomycotina archived in FSD (Continued)

\begin{tabular}{|c|c|c|c|c|c|c|c|}
\hline Saccharomyces cerevisiae Y9 & 12.6 & 5,377 & 223 & 271 & 49 & 543 & {$[81]$} \\
\hline Saccharomyces cerevisiae Yllc17_E5 & 12.5 & 5,376 & 227 & 265 & 47 & 539 & {$[81]$} \\
\hline Saccharomyces cerevisiae YJM789 & 12.0 & 5,903 & 293 & 303 & 59 & 655 & [84] \\
\hline Saccharomyces cerevisiae YJM975 & 12.4 & 5,341 & 223 & 255 & 45 & 523 & {$[81]$} \\
\hline Saccharomyces cerevisiae YJM978 & 12.4 & 5,353 & 224 & 258 & 47 & 529 & {$[81]$} \\
\hline Saccharomyces cerevisiae YJM981 & 12.5 & 5,351 & 224 & 256 & 54 & 534 & {$[81]$} \\
\hline Saccharomyces cerevisiae YPS128 & 12.4 & 5,364 & 230 & 269 & 54 & 553 & {$[81]$} \\
\hline Saccharomyces cerevisiae YPS163 & 10.7 & 6,648 & 229 & 368 & 67 & 664 & {$[82]$} \\
\hline Saccharomyces cerevisiae YPS606 & 12.5 & 5,354 & 224 & 270 & 51 & 545 & {$[81]$} \\
\hline Saccharomyces cerevisiae YS2 & 12.6 & 5,383 & 221 & 254 & 50 & 525 & {$[81]$} \\
\hline Saccharomyces cerevisiae YS4 & 12.5 & 5,398 & 215 & 267 & 54 & 536 & {$[81]$} \\
\hline Saccharomyces cerevisiae YS9 & 12.6 & 5,373 & 226 & 265 & 51 & 542 & {$[81]$} \\
\hline Saccharomyces kluyveri & 11.0 & 2,968 & 120 & 180 & 29 & 329 & {$[79]$} \\
\hline Saccharomyces kudriavzevii & 11.2 & 3,768 & 187 & 195 & 28 & 410 & {$[79]$} \\
\hline Saccharomyces mikatae & 11.5 & 9,016 & 575 & 630 & 154 & 1359 & {$[80]$} \\
\hline Saccharomyces mikatae WashU & 10.8 & 3,100 & 161 & 154 & 24 & 339 & {$[79]$} \\
\hline Saccharomyces paradoxus & 11.9 & 8,939 & 581 & 615 & 138 & 1334 & {$[80]$} \\
\hline Yarrowia lipolytica & 20.5 & 6,524 & 409 & 464 & 75 & 948 & {$[73]$} \\
\hline \multicolumn{8}{|l|}{ Taphrinomycotina (Subphylum) } \\
\hline Pneumocystis carinii ${ }^{\mathrm{b}, \mathrm{c}}$ & 6.3 & 4,020 & 129 & 333 & 35 & 497 & $\mathrm{~N}$ \\
\hline Schizosaccharomyces japonicus & 11.3 & 5,172 & 207 & 312 & 25 & 544 & $\mathrm{~N}$ \\
\hline Schizosaccharomyces octosporus & 11.2 & 4,925 & 190 & 263 & 26 & 479 & $\mathrm{~N}$ \\
\hline Schizosaccharomyces pombe & 12.6 & 5,058 & 192 & 288 & 36 & 516 & [85] \\
\hline Total & 853.1 & 383,828 & 17,389 & 21,403 & 3,937 & 42,729 & - \\
\hline
\end{tabular}

recent phylogenomic studies [37-39], contain 22.31\% and $16.93 \%$ of secretory proteins, respectively. Moreover, the same tendency was found in comparison with 158 fungal/oomycete genomes archived in the FSD (pathogens and saprophytes showed 14.06\% and $11.70 \%$, respectively).

\section{Effectors encoded by fungal/oomycete and Plasmodium} genomes

Phytophthora species, a group that includes many important plant pathogens, uses a RXLR signal to secrete effectors to host cells [40]. RXLR effectors were tightly co-located with signal peptides predicted by the SignalP 3.0 with high confidence values (HMM and NN for 0.93 and 0.65 , respectively) [41]. With the same conditions, we identified 734 putative RXLR effectors from three Phytophthora species, similar to a previous study [42]. However, 153 fungal genomes showed that only $0.04 \%$ of the total proteome contained this motif, suggesting that the use of RXLR for secretion is oomycetespecific.

The motivation of finding the RXLR pattern in oomycetes was the RXLX [EDQ] motif of the VTS in the malaria pathogen, Plasmodium falciparum. Once
P. falciparum invades the human erythrocyte, it secretes the proteins that carry the pentameric VTS of the RXLX [EDQ] motif from the parasitophorus vacuole to the host cytoplasm $[12,13]$. To determine how many VTSs could be detected by our pipeline, we investigated 217 proteins of $P$. falciparum [13]. Of these, 115 proteins $(53.00 \%)$ were classified as secretory proteins, defined in the FSD by the RXLX [EDQ] motif. Comparing our result to that predicted by SignalP 3.0 alone (41 out of 217), we found that our pipeline demonstrated high fidelity in detecting proteins containing VTSs.

In class SP, the proportions of proteins possessing the RXLX [EDQ] but not the RXLR motif were 96.75\%, $56.18 \%$, and $93.21 \%$ in fungi, oomycetes, and Plasmodium species, respectively (Figure 3A). There were similar proportions of the RXLX [EDQ] motif in classes $\mathrm{SP}^{3}$ and SL across the three groups (Figure $3 \mathrm{~B}$ and $3 \mathrm{C}$ ). Taken together, these data show that the RXLR motif, with signal peptides predicted by SignalP 3.0, is oomycete-specific [41]. It is interesting that fungal genomes have significantly higher numbers of the RXLX [EDQ] motif than Plasmodium species ( $\mathrm{t}$-test based on amino acid frequency in each genome; $\left.P=2.2 \mathrm{e}^{-16}\right)$, suggesting 
Table 6 List and distribution of secretion-associated proteins of the fungal genomes belonging to the phyla Basidiomycota, Chytridiomycota, and Microsporidia, the subphylum Mucoromycotina, and the phylum Peronosporomycota (oomycetes) archived in FSD

\begin{tabular}{|c|c|c|c|c|c|c|c|}
\hline Species & Size $(\mathrm{Mb})$ & \# of ORFs & Class SP & Class $\mathrm{SP}^{3}$ & Class SL & Putative Secretome & Ref \\
\hline \multicolumn{8}{|l|}{ Fungi (Kingdom) ${ }^{\mathrm{a}}$} \\
\hline \multicolumn{8}{|l|}{ Basidiomycota (Phylum) } \\
\hline \multicolumn{8}{|l|}{ Agricomycotina (Subphylum) } \\
\hline Coprinus cinereus & 36.3 & 13,410 & 1,189 & 1,032 & 119 & 2,340 & N \\
\hline Cryptococcus neoformans Serotype A & 18.9 & 6,980 & 377 & 549 & 56 & 982 & N \\
\hline Cryptococcus neoformans Serotype B & 19.0 & 6,870 & 331 & 529 & 44 & 904 & N \\
\hline Cryptococcus neoformans Serotype D B-3501A & 18.5 & 6,431 & 342 & 523 & 39 & 904 & {$[86]$} \\
\hline Cryptococcus neoformans Serotype D JEC21 & 19.1 & 6,475 & 344 & 541 & 38 & 923 & {$[86]$} \\
\hline Laccaria bicolour & 64.9 & 20,614 & 1,190 & 2,024 & 256 & 3,470 & {$[87]$} \\
\hline Moniliophthora perniciosa & 26.7 & 13,560 & 843 & 1,127 & 126 & 2,096 & N \\
\hline Phanerochaete chrysosporium & 35.1 & 10,048 & 793 & 933 & 83 & 1,809 & {$[88]$} \\
\hline Pleurotus ostreatus & 34.3 & 11,603 & 1,039 & 1,058 & 106 & 2,203 & N \\
\hline Postia placenta & 90.9 & 17,173 & 1,057 & 1,808 & 202 & 3,067 & {$[51]$} \\
\hline Schizophyllum commune & 38.5 & 13,181 & 975 & 1,175 & 119 & 2,269 & $\mathrm{~N}$ \\
\hline \multicolumn{8}{|l|}{ Pucciniomycotina (Subphylum) } \\
\hline Melampsora laricis-populina & 21.9 & 16,694 & 1305 & 1483 & 233 & 3,021 & $\mathrm{~N}$ \\
\hline Puccinia graminis & 88.7 & 20,567 & 1,931 & 2,020 & 230 & 4,181 & $\mathrm{~N}$ \\
\hline Sporobolomyces roseus & 21.2 & 5,536 & 187 & 592 & 43 & 822 & $\mathrm{~N}$ \\
\hline \multicolumn{8}{|l|}{ Ustilaginomycotina (Subphylum) } \\
\hline Malassezia globosa & 9.0 & 4,286 & 211 & 378 & 37 & 626 & {$[50]$} \\
\hline Ustilago maydis 521 & 19.7 & 6,689 & 789 & 583 & 10 & 1382 & {$[89]$} \\
\hline Ustilago maydis FB1 & 19.3 & 6,950 & 481 & 717 & 34 & 1232 & {$[89]$} \\
\hline Ustilago maydis MIPS & 19.7 & 6,787 & 574 & 687 & 34 & 1295 & $\mathrm{~N}$ \\
\hline \multicolumn{8}{|l|}{ Chytridiomycota (Phylum) } \\
\hline Batrachochytrium dendrobatidis JAM81 & 24.3 & 8,732 & 806 & 750 & 108 & 1,664 & $\mathrm{~N}$ \\
\hline Batrachochytrium dendrobatidis JEL423 & 23.9 & 8,818 & 650 & 785 & 91 & 1,526 & N \\
\hline \multicolumn{8}{|l|}{ Mucoromycotina (Subphylum incertae sedis) } \\
\hline Mucor circinelloides & 36.6 & 10,930 & 580 & 623 & 83 & 1286 & $\mathrm{~N}$ \\
\hline Phycomyces blakesleeanus & 55.9 & 14,792 & 642 & 1,085 & 221 & 1,948 & $\mathrm{~N}$ \\
\hline Rhizopus oryzae & 46.1 & 17,482 & 750 & 994 & 202 & 1,946 & [90] \\
\hline \multicolumn{8}{|l|}{ Microsporidia (Phylum) } \\
\hline Antonospora locustae & 6.1 & 2,606 & 166 & 208 & 62 & 436 & N \\
\hline Encephalitozoon cuniculi & 2.5 & 1,996 & 90 & 135 & 34 & 259 & [91] \\
\hline \multicolumn{8}{|l|}{ Alveolata (Kingdom) } \\
\hline \multicolumn{8}{|l|}{ Apicomplexa (Phylum) } \\
\hline Plasmodium berghei & 18.0 & 12,175 & 844 & 554 & 569 & 1,967 & $\mathrm{~N}$ \\
\hline Plasmodium chabaudi & 16.9 & 15,007 & 1,027 & 643 & 661 & 2,331 & $\mathrm{~N}$ \\
\hline Plasmodium falciparum 3D7 & 21.0 & 5,387 & 212 & 283 & 267 & 762 & [92] \\
\hline Plasmodium knowlesi & 23.5 & 5,103 & 305 & 280 & 81 & 666 & $\mathrm{~N}$ \\
\hline \multicolumn{8}{|l|}{ Stramenopila (Kingdom) } \\
\hline \multicolumn{8}{|l|}{ Peronosporomycota (Phylum) } \\
\hline Hyaloperonospora parasitica & 83.6 & 14,789 & 868 & 1,235 & 132 & 2,235 & $\mathrm{~N}$ \\
\hline Phytophthora capsici & 107.8 & 17,414 & 1,485 & 1,179 & 136 & 2,800 & N \\
\hline Phytophthora infestans ${ }^{\mathrm{b}}$ & 228.5 & 22,658 & 1,668 & 1,923 & 153 & 3,744 & [93] \\
\hline Phytophthora ramorum & 66.7 & 15,743 & 1,670 & 1,372 & 91 & 3,133 & [94] \\
\hline Phytophthora sojae & 86.0 & 19,027 & 2,040 & 1,662 & 96 & 3,798 & [94] \\
\hline Total & $1,449.1$ & 386,513 & 27,761 & 31,470 & 4,796 & 64,027 & - \\
\hline
\end{tabular}

\footnotetext{
a Taxonomy based on [69]

${ }^{b}$ Insufficient exon/intron information

c Incomplete coverage of genome information
} 


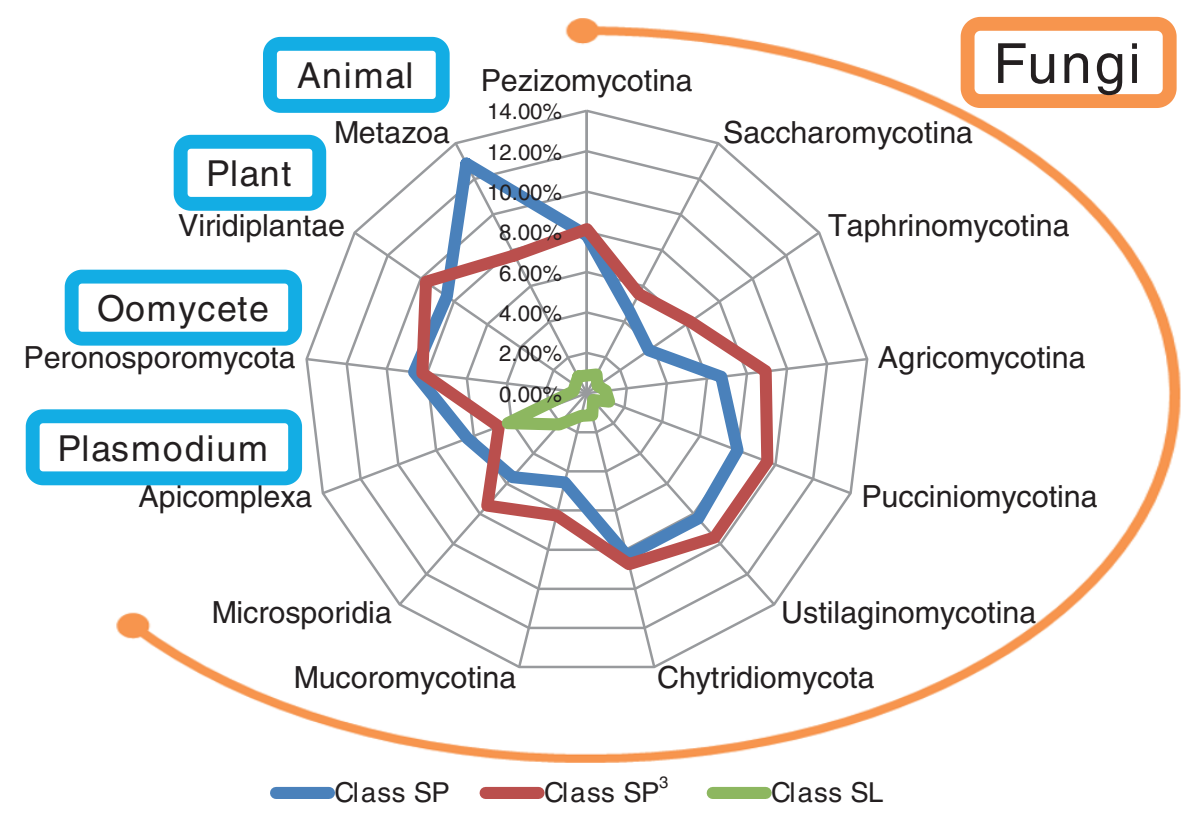

Figure 2 Distribution of three classes at the phylum/subphylum level. The average ratios of the classes to the total ORFs at the subphylum and phylum levels are described. The orange circular arc represents the fungal kingdom, and the four light blue round boxes represent phyla or kingdoms. Inside the chart, the blue line represents the ratio of class SP; the red line, class SP3; and the green line, class SL.
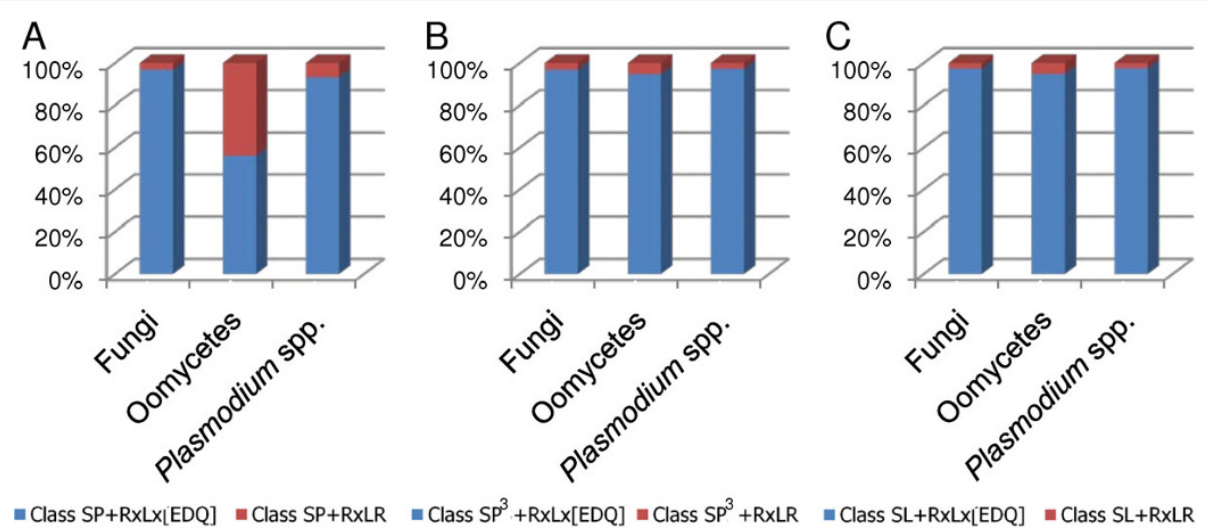

Figure 3 Composition of RXLR/RXLX [EDQ] pattern in fungi, oomycetes, and Plasmodium species. Composition of the RXLX [EDQ] (blue) and the RXLR (red) under class SP (A), class SP ${ }^{3}(B)$, and class SL (C) with the relative ratio in fungi, oomycetes, and Plasmodium species, respectively.

that the RXLX [EDQ] motif may be one of fungal-specific signatures of effectors.

\section{Utility}

\section{FSD web interfaces}

To support the browsing of the global patterns of archived data, the FSD prepares diverse charts and tables. For example, intersections of prediction results are summarized in a chart for each genome (Figure 4). Despite of the many programs, all prediction results for each protein are displayed on one page, allowing users to browse them easily (Figure 5).
The SNUGB interface (http://genomebrowser.snu.ac. $\mathrm{kr} /$ )[15] provides several fields: i) signal peptides predicted by four different programs; ii) effector patterns, such as RXLR and RXLX [EDQ]; iii) nucleotide localization signals predicted by predictNLS; iv) transmembrane helixes predicted by TMHMM 2.0c; and v) hydropathy plots (Figure 6). The users can readily compare secretome-related information with diverse genomic contexts. The personalized virtual space, Favorite, supports in-depth analyses in the FSD

The FSD allows users to collect proteins of interest and save them into the Favorite, which provides thirteen 


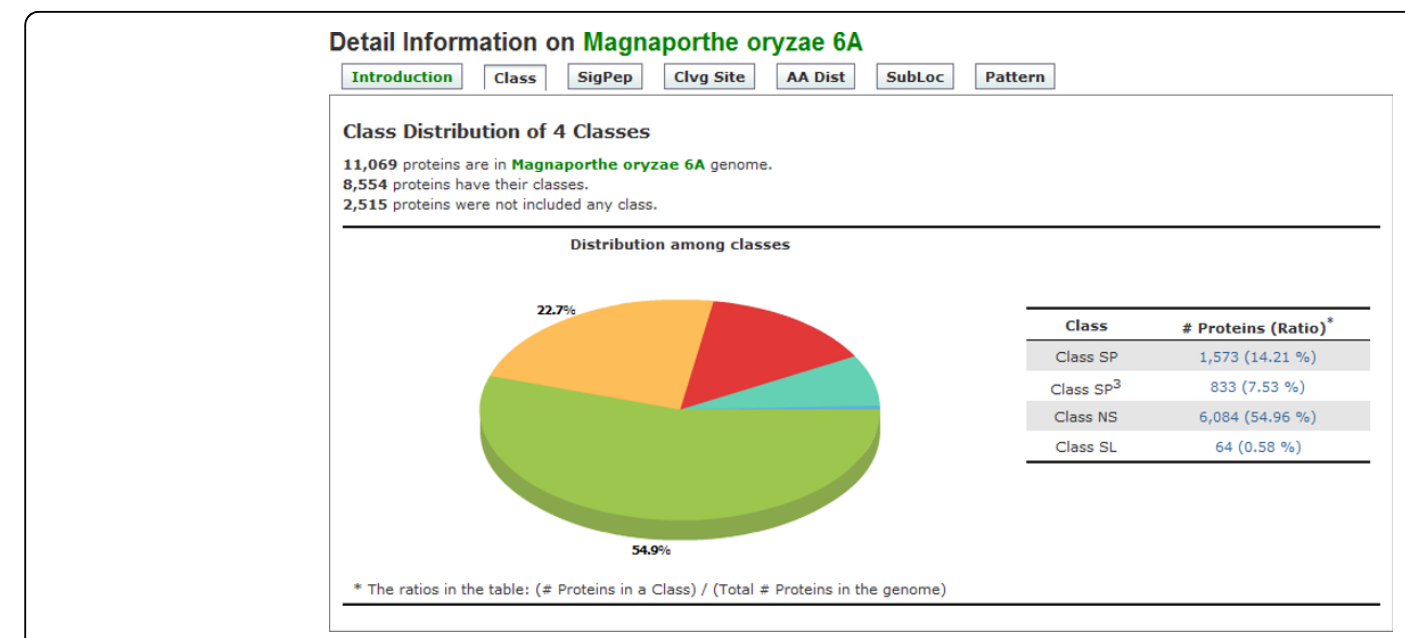

Figure 4 Screenshot of genome-level analysis functions for an example fungal genome. This screenshot shows the ORF numbers and ratios of each class through the pie chart in the left and the table in the right. The numbers in the table provide links to the list of putative secretory proteins belonging to each group. This figure shows the result from M. oryzae.
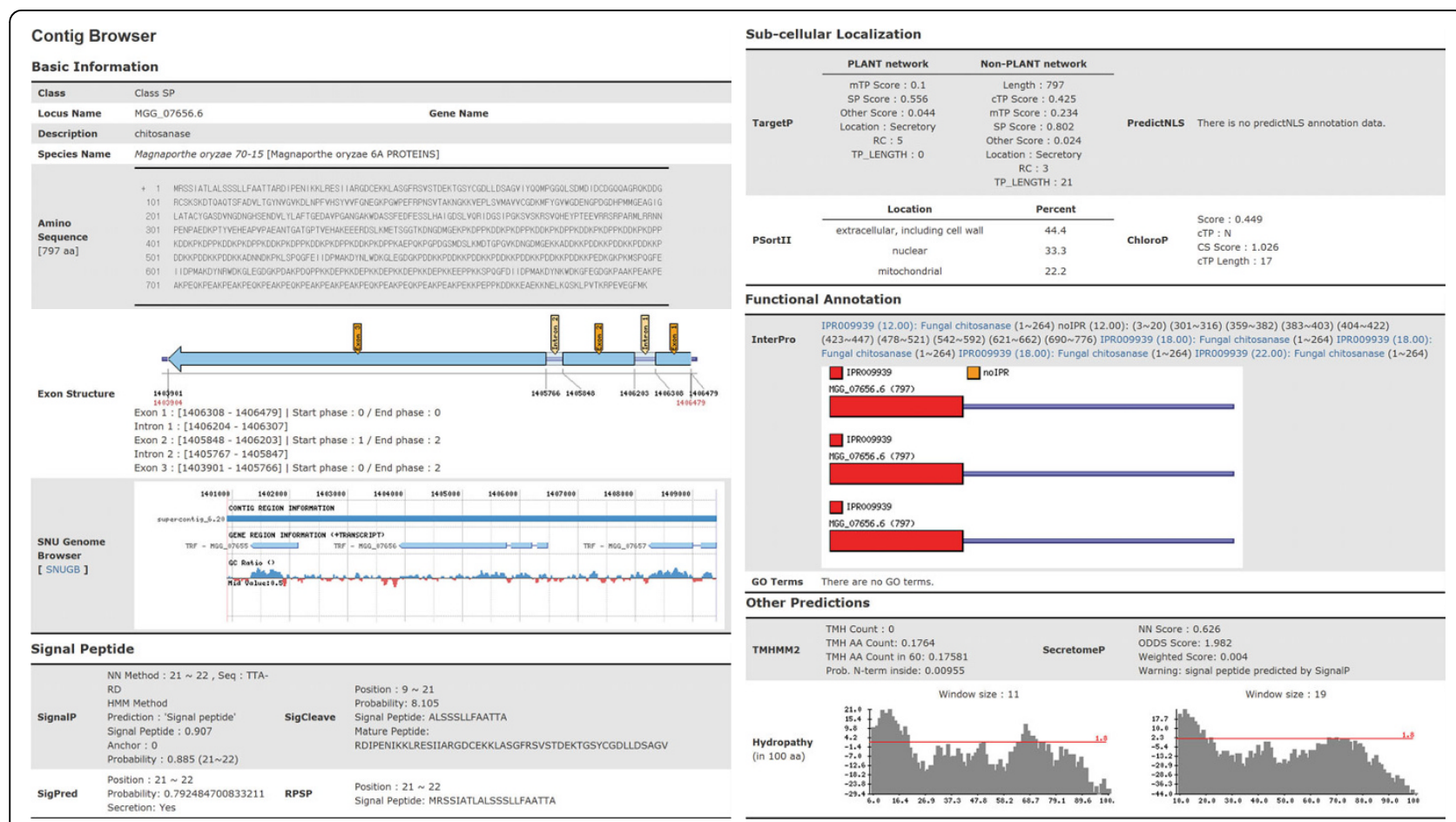

Figure 5 One page summary for a protein. The web page shows a one page summary of amino acid sequence, exon structure, and genome context via the SNUGB [15], along with 12 predictions, including signal peptides and subcellular localization.

functions: i) classes distribution of proteins; ii) comparisons of predicted signal peptides generated by the four programs; iii) distributions and lists of proteins with predicted signal peptide cleavage sites; iv) compositions of amino acids near the cleavage sites; v) analyses of subcellular localization predictions; vi) lists and ratios of proteins that have chloroplast transit peptides, as determined by ChloroP 1.1; vii) analyses of proteins detected by SecretomeP 1.0f; viii) lists and distribution charts of proteins with trans-membrane helices, as predicted by TMHMM 2.0c; ix) hydropathy plots for proteins; $x$ ) analyses of proteins believed to be targeted to the nucleus of a host cell supported by predictNLS; xi) distributions and lists of proteins with a specific amino acid patterns; xii) lists of functional domains predicted by InterPro Scan; xiii) domain architecture of InterPro Scan (Figure 


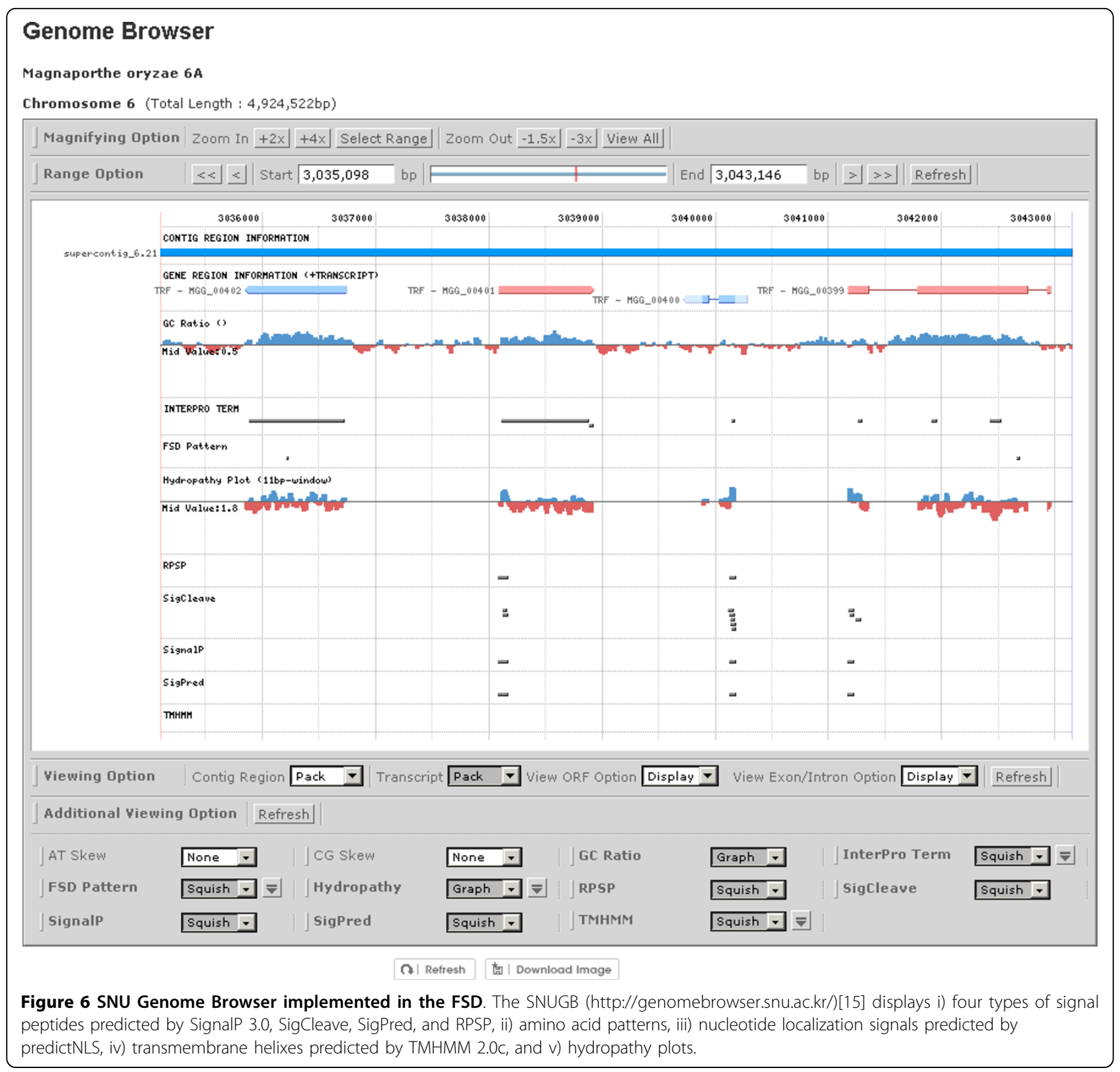

7). From these result pages, users can collect and store proteins in Favorite again, for further analyses. Additionally, Favorites created in the FSD can be shared with the CFGP (http://cfgp.snu.ac.kr/)[16], permitting users to use the 22 bioinformatics tools provided in the CFGP web site.

\section{Conclusions}

Given the availability of large number of fungal genomes and diverse prediction programs for secretory proteins, a three-layer classification rule was established and implemented in a web-based database, the FSD. With the aid of an automated pipeline, the FSD classifies putative secretory proteins from 158 fungal/ oomycetes genomes into four different classes, three of which are defined as the putative secretome. The proportion of fungal secretory proteins and host targeting signals varies considerably by species. It is interesting that fungal genomes have high proportions of the RXLX [EDQ] motif, characterized as host targeting signal in Plasmodium species. Summaries of the complex prediction results from twelve programs help users to readily access to the information provided by the FSD. Favorite, a personalized virtual space in the CFGP, serves thirteen different analysis tools for further indepth analyses. Moreover, 22 bioinformatics tools 


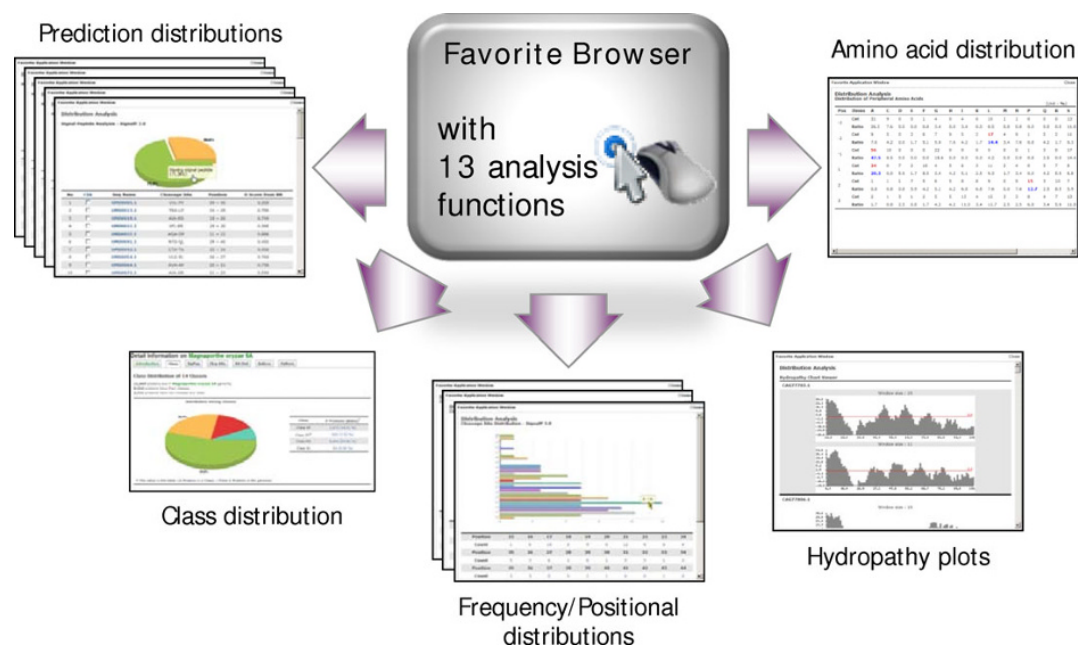

Figure 7 Thirteen analysis functions in the Favorite browser. Six different pages of analyses, connected to the Favorite browser, are displayed. "Prediction distribution" provides a list of predicted secretory proteins with their proportion to all proteins. "Class distribution" shows the composition of the classes, with the protein numbers belonging to each class. "Frequency/Position distribution" gives a bar or pie graph and numerical values linking to proteins listed for each item. "Hydropathy plots" draws the two graphs with window sizes of 11 and 19 . "Amino acid distribution" presents consensus amino acids around the cleavage sites. "Functional domain distribution" lists the domains and their architecture diagrams based on InterPro terms.

provided by the CFGP can be utilized via the Favorite. Given these features, the FSD can serve as an integrated environment for studying secretory proteins in the fungal kingdom.

\section{Availability and requirements}

All data and functions described in this paper can be freely accessed through the FSD web site at http://fsd. snu.ac.kr/.

\section{Acknowledgements}

This work was supported by the National Research Foundation of Korea grants (2009-0063340 and 2009-0080161) and grants from the Biogreen21 (20080401-034-044-009-01-00), the TDPAF (309015-04-SB020), and the Crop Functional Genomics Center (2009K001198). JC is grateful for the graduate fellowship through the Brain Korea 21 Program.

\section{Author details}

${ }^{1}$ Fungal Bioinformatics Laboratory, Seoul National University, Seoul 151-921, Korea. ${ }^{2}$ Department of Agricultural Biotechnology, Seoul National University, Seoul 151-921, Korea. ${ }^{3}$ Center for Fungal Pathogenesis, Seoul National University, Seoul 151-921, Korea. ${ }^{4}$ Center for Fungal Genetic Resources, Seoul National University, Seoul 151-921, Korea. ${ }^{5}$ Center for Agricultural Biomaterials, Seoul National University, Seoul 151-921, Korea. ${ }^{6}$ Department of Plant Pathology, The Pennsylvania State University, University Park, PA 16802, USA.

\section{Authors' contributions}

$J C, J P$, and YHL designed this project, JC and JP constructed the database and developed the pipeline with nine prediction programs. DK generated basic data from the twelve programs and JP, JC, and DK managed genome sequences for FSD. JC developed thirteen analysis functions of FSD. JC and JP constructed web-based interfaces. JC, JP, SK, and YHL wrote the manuscript. All the authors read and confirmed the manuscript.

\section{References}

1. Lippincott-Schwartz J, Roberts TH, Hirschberg K: Secretory protein trafficking and organelle dynamics in living cells. Annu Rev Cell Dev Biol 2000, 16:557-589.

2. Abbas KA, Lichtman HA, Pillai S: Cellular and Molecular Immunilogy Saunders, 62006.

3. Cho WJ, Jeremic A, Rognlien KT, Zhvania MG, Lazrishvili I, Tamar B, Jena BP: Structure, isolation, composition and reconstitution of the neuronal fusion pore. Cell Biol Int 2004, 28(10):699-708.

4. Cho SJ, Jeftinija K, Glavaski A, Jeftinija S, Jena BP, Anderson LL: Structure and dynamics of the fusion pores in live $\mathrm{GH}$-secreting cells revealed using atomic force microscopy. Endocrinology 2002, 143(3):1144-1148.

5. Suarez MB, Sanz L, Chamorro Ml, Rey M, Gonzalez FJ, Llobell A, Monte E: Proteomic analysis of secreted proteins from Trichoderma harzianum: Identification of a fungal cell wall-induced aspartic protease. Fungal Genet Biol 2005, 42(11):924-934.

6. Van den Wymelenberg A, Minges $P$, Sabat G, Martinez $D$, Aerts A, Salamov A, Grigoriev I, Shapiro H, Putnam N, Belinky P, Dosoretz C, Gaskell J, Kersten P, Cullen D: Computational analysis of the Phanerochaete chrysosporium v2.0 genome database and mass spectrometry identification of peptides in ligninolytic cultures reveal complex mixtures of secreted proteins. Fungal Genet Biol 2006, 43(5):343-356

7. Vinzant TB, Adney WS, Decker SR, Baker JO, Kinter MT, Sherman NE, Fox JW, Himmel ME: Fingerprinting Trichoderma reesei hydrolases in a commercial cellulase preparation. Appl Biochem Biotechnol 2001, 9193:99-107.

8. Lesage G, Bussey H: Cell wall assembly in Saccharomyces cerevisiae. Microbiol Mol Biol Rev 2006, 70(2):317-343.

9. Waters CM, Bassler BL: Quorum sensing: cell-to-cell communication in bacteria. Annu Rev Cell Dev Biol 2005, 21:319-346.

10. Cornelis GR, Van Gijsegem F: Assembly and function of type III secretory systems. Annu Rev Microbiol 2000, 54:735-774.

11. Kamoun S: A catalogue of the effector secretome of plant pathogenic oomycetes. Annu Rev Phytopathol 2006, 44:41-60.

12. Hiller NL, Bhattacharjee S, van Ooij C, Liolios K, Harrison T, Lopez-Estrano C, Haldar K: A host-targeting signal in virulence proteins reveals a secretome in malarial infection. Science 2004, 306(5703):1934-1937.

13. Marti M, Good RT, Rug M, Knuepfer E, Cowman AF: Targeting malaria virulence and remodeling proteins to the host erythrocyte. Science 2004, 306(5703):1930-1933. 
14. Bouws $H$, Wattenberg A, Zorn H: Fungal secretomes-nature's toolbox for white biotechnology. Appl Microbiol Biotechnol 2008, 80(3):381-388.

15. Jung K, Park J, Choi J, Park B, Kim S, Ahn K, Choi J, Choi D, Kang S, Lee Y-H: SNUGB: a versatile genome browser supporting comparative and functional fungal genomics. BMC Genomics 2008, 9:585.

16. Park J, Park B, Jung K, Jang S, Yu K, Choi J, Kong S, Kim S, Kim H, Kim JF, Blair JE, Lee K, Kang S, Lee YH: CFGP: a web-based, comparative fungal genomics platform. Nucleic Acids Res 2008, 36:D562-571.

17. Bendtsen JD, Nielsen H, von Heijne G, Brunak S: Improved prediction of signal peptides: SignalP 3.0. J Mol Biol 2004, 340(4):783-795.

18. Choo KH, Tan TW, Ranganathan S: SPdb-a signal peptide database. BMC Bioinformatics 2005, 6:249.

19. Rice P, Longden I, Bleasby A: EMBOSS: the European Molecular Biology Open Software Suite. Trends Genet 2000, 16(6):276-277.

20. Bradford JR: Protein Design for Biopharmaceutical Development at GlaxoSmithKline: In silico Methods for Prediction of Signal Peptides and their Cleavage Sites, and Linear Epitopes. MRes thesis, The University of Leeds, Department of Biological Sciences 2001

21. Plewczynski D, Slabinski L, Ginalski K, Rychlewski L: Prediction of signal peptides in protein sequences by neural networks. Acta Biochim Pol 2008, 55(2):261-267.

22. Horton P, Park KJ, Obayashi T, Fujita N, Harada H, Adams-Collier CJ, Nakai K: WoLF PSORT: protein localization predictor. Nucleic Acids Res 2007, 35(Web Server issue):W585-587.

23. Emanuelsson O, Nielsen H, Brunak S, von Heijne G: Predicting subcellular localization of proteins based on their $\mathrm{N}$-terminal amino acid sequence. J Mol Biol 2000, 300(4):1005-1016.

24. Kumar A, Agarwal S, Heyman JA, Matson S, Heidtman M, Piccirillo S, Umansky L, Drawid A, Jansen R, Liu Y, Cheung KH, Miller P, Gerstein M, Roeder GS, Snyder M: Subcellular localization of the yeast proteome. Genes Dev 2002, 16(6):707-719.

25. Bendtsen JD, Jensen $\sqcup$, Blom N, Von Heijne G, Brunak S: Feature-based prediction of non-classical and leaderless protein secretion. Protein Eng Des Sel 2004, 17(4):349-356.

26. Sonnhammer EL, von Heijne G, Krogh A: A hidden Markov model for predicting transmembrane helices in protein sequences. Proc Int Conf Intell Syst Mol Biol 1998, 6:175-182.

27. Raykhel I, Alanen H, Salo K, Jurvansuu J, Nguyen VD, Latva-Ranta M, Ruddock L: A molecular specificity code for the three mammalian KDEL receptors. J Cell Biol 2007, 179(6):1193-1204.

28. Cokol M, Nair R, Rost B: Finding nuclear localization signals. EMBO Rep 2000, 1(5):411-415.

29. Park J, Park J, Jang S, Kim S, Kong S, Choi J, Ahn K, Kim J, Lee S, Kim S, Park B, Jung K, Kim S, Kang S, Lee YH: FTFD: an informatics pipeline supporting phylogenomic analysis of fungal transcription factors. Bioinformatics 2008, 24(7):1024-1025.

30. Jeon J, Park SY, Chi MH, Choi J, Park J, Rho HS, Kim S, Goh J, Yoo S, Choi J, Park JY, Yi M, Yang S, Kwon MJ, Han SS, Kim BR, Khang CH, Park B, Lim SE, Jung K, Kong S, Karunakaran M, Oh HS, Kim H, Kim S, Park J, Kang S, Choi WB, Kang S, Lee YH: Genome-wide functional analysis of pathogenicity genes in the rice blast fungus. Nat Genet 2007, 39(4):561-565.

31. Park J, Lee S, Choi J, Ahn K, Park B, Park J, Kang S, Lee YH: Fungal Cytochrome P450 Database. BMC Genomics 2008, 9(1):402

32. Choi J, Park J, Jeon J, Chi MH, Goh J, Yoo SY, Park J, Jung K, Kim H, Park SY, Rho HS, Kim S, Kim BR, Han SS, Kang S, Lee YH: Genome-wide analysis of T-DNA integration into the chromosomes of Magnaporthe oryzae. Mol Microbiol 2007, 66(2):371-382.

33. Lee W, Park J, Choi J, Jung K, Park B, Kim D, Lee J, Ahn K, Song W, Kang S, Lee YH, Lee S: IMGD: an Integrated Platform Supporting Comparative Genomics and Phylogenetics of Insect Mitochondrial Genomes. BMC Genomics 2009, 10:148.

34. Park J, Park B, Veeraraghavan N, Jung K, Lee YH, Blair J, Geiser DM, Isard S, Mansfield MA, Nikolaeva E, Park SY, Russo J, Kim SH, Greene M, Ivors KL, Balci Y, Peiman M, Erwin DC, Coffey MD, Rossman A, Farr D, Cline E, Crünwald NJ, Luster DG, Schrandt J, Martin F, Ribeiro OK, Makalowska I, Kang S: Phytophthora Database: A Forensic Database Supporting the Identification and Monitoring of Phytophthora. Plant disease 2008, 92(6):966-972.
35. Xi H, Park J, Ding G, Lee YH, Li Y: SysPIMP: the web-based systematical platform for identifying human disease-related mutated sequences from mass spectrometry. Nucleic Acids Res 2009, 37:D913-920.

36. Kyte J, Doolittle RF: A simple method for displaying the hydropathic character of a protein. J Mol Biol 1982, 157(1):105-132.

37. Fitzpatrick DA, Logue ME, Stajich JE, Butler G: A fungal phylogeny based on 42 complete genomes derived from supertree and combined gene analysis. BMC Evol Biol 2006, 6:99.

38. Wang $\mathrm{H}, \mathrm{Xu} \mathrm{Z}$, Gao L, Hao B: A fungal phylogeny based on 82 complete genomes using the composition vector method. BMC Evol Biol 2009, 9:195.

39. Soanes DM, Alam I, Cornell M, Wong HM, Hedeler C, Paton NW, Rattray M, Hubbard SJ, Oliver SG, Talbot NJ: Comparative genome analysis of filamentous fungi reveals gene family expansions associated with fungal pathogenesis. PLoS One 2008, 3(6):e2300.

40. Whisson SC, Boevink PC, Moleleki L, Avrova AO, Morales JG, Gilroy EM, Armstrong MR, Grouffaud S, van West P, Chapman S, Hein I, Toth IK, Pritchard L, Birch PR: A translocation signal for delivery of oomycete effector proteins into host plant cells. Nature 2007, 450(7166):115-118.

41. Win J, Morgan W, Bos J, Krasileva KV, Cano LM, Chaparro-Garcia A, Ammar R, Staskawicz BJ, Kamoun S: Adaptive evolution has targeted the C-terminal domain of the RXLR effectors of plant pathogenic oomycetes. Plant Cell 2007, 19(8):2349-2369.

42. Jiang RH, Tripathy S, Govers F, Tyler BM: RXLR effector reservoir in two Phytophthora species is dominated by a single rapidly evolving superfamily with more than 700 members. Proc Natl Acad Sci USA 2008, 105(12):4874-4879.

43. Qin G, Tian S, Chan Z, Li B: Crucial role of antioxidant proteins and hydrolytic enzymes in pathogenicity of Penicillium expansum: analysis based on proteomics approach. Mol Cell Proteomics 2007, 6(3):425-438.

44. Wymelenberg AV, Sabat G, Martinez D, Rajangam AS, Teeri TT, Gaskell J, Kersten PJ, Cullen D: The Phanerochaete chrysosporium secretome: database predictions and initial mass spectrometry peptide identifications in cellulose-grown medium. J Biotechnol 2005, 118(1):17-34.

45. Lee SA, Wormsley S, Kamoun S, Lee AF, Joiner K, Wong B: An analysis of the Candida albicans genome database for soluble secreted proteins using computer-based prediction algorithms. Yeast 2003, 20(7):595-610.

46. Mueller O, Kahmann R, Aguilar G, Trejo-Aguilar B, Wu A, de Vries RP: The secretome of the maize pathogen Ustilago maydis. Fungal Genet Biol 2008, 45(Suppl 1):S63-70.

47. Abbas A, Koc H, Liu F, Tien M: Fungal degradation of wood: initial proteomic analysis of extracellular proteins of Phanerochaete chrysosporium grown on oak substrate. Curr Genet 2005, 47(1):49-56.

48. Paper JM, Scott-Craig JS, Adhikari ND, Cuomo CA, Walton JD: Comparative proteomics of extracellular proteins in vitro and in planta from the pathogenic fungus Fusarium graminearum. Proteomics 2007, 7(17):3171-3183.

49. Sato $\mathrm{S}$, Liu $\mathrm{F}, \mathrm{KoC} \mathrm{H}$, Tien M: Expression analysis of extracellular proteins from Phanerochaete chrysosporium grown on different liquid and solid substrates. Microbiology 2007, 153(Pt 9):3023-3033.

50. Xu J, Saunders CW, Hu P, Grant RA, Boekhout T, Kuramae EE, Kronstad JW, Deangelis YM, Reeder NL, Johnstone KR, Leland M, Fieno AM, Begley WM, Sun Y, Lacey MP, Chaudhary T, Keough T, Chu L, Sears R, Yuan B, Dawson TL Jr: Dandruff-associated Malassezia genomes reveal convergent and divergent virulence traits shared with plant and human fungal pathogens. Proc Natl Acad Sci USA 2007, 104(47):18730-18735.

51. Martinez D, Challacombe J, Morgenstern I, Hibbett D, Schmoll M, Kubicek CP, Ferreira P, Ruiz-Duenas FJ, Martinez AT, Kersten P, Hammel KE, Vanden Wymelenberg A, Gaskell J, Lindquist E, Sabat G, Bondurant SS, Larrondo LF, Canessa P, Vicuna R, Yadav J, Doddapaneni H, Subramanian V, Pisabarro AG, Lavin JL, Oguiza JA, Master E, Henrissat B, Coutinho PM, Harris P, Magnuson JK, et al: Genome, transcriptome, and secretome analysis of wood decay fungus Postia placenta supports unique mechanisms of lignocellulose conversion. Proc Natl Acad Sci USA 2009, 106(6):1954-1959.

52. Chisholm ST, Coaker G, Day B, Staskawicz BJ: Host-microbe interactions: shaping the evolution of the plant immune response. Cell 2006, 124(4):803-814.

53. Wortman JR, Fedorova N, Crabtree J, Joardar V, Maiti R, Haas BJ, Amedeo P, Lee E, Angiuoli SV, Jiang B, Anderson MJ, Denning DW, White OR, Nierman WC: Whole genome comparison of the A. fumigatus family. Med Mycol 2006, 44(6):3-7. 
54. Fedorova ND, Khaldi N, Joardar VS, Maiti R, Amedeo P, Anderson MJ, Crabtree J, Silva JC, Badger JH, Albarraq A, Angiuoli S, Bussey H, Bowyer P, Cotty PJ, Dyer PS, Egan A, Galens K, Fraser-Liggett CM, Haas BJ, Inman JM, Kent R, Lemieux S, Malavazi I, Orvis J, Roemer T, Ronning CM, Sundaram JP, Sutton G, Turner G, Venter JC, et al: Genomic islands in the pathogenic filamentous fungus Aspergillus fumigatus. PLoS Genet 2008, 4(4):e1000046.

55. Payne GA, Nierman WC, Wortman JR, Pritchard BL, Brown D, Dean RA, Bhatnagar D, Cleveland TE, Machida M, Yu J: Whole genome comparision of A. flavus and A. oryzae. Med Mycol 2006, 44(6):9-11.

56. Nierman WC, Pain A, Anderson MJ, Wortman JR, Kim HS, Arroyo J, Berriman M, Abe K, Archer DB, Bermejo C, Bennett J, Bowyer P, Chen D, Collins M, Coulsen R, Davies R, Dyer PS, Farman M, Fedorova N, Fedorova N, Feldblyum TV, Fischer R, Fosker N, Fraser A, Garcia JL, Garcia MJ, Goble A, Goldman GH, Gomi K, Griffith-Jones S, et al: Genomic sequence of the pathogenic and allergenic filamentous fungus Aspergillus fumigatus. Nature 2005, 438(7071):1151-1156.

57. Galagan JE, Calvo SE, Cuomo C, Ma LJ, Wortman JR, Batzoglou S, Lee SI, Basturkmen M, Spevak CC, Clutterbuck J, Kapitonov V, Jurka J, Scazzocchio C, Farman M, Butler J, Purcell S, Harris S, Braus GH, Draht O, Busch S, D'Enfert C, Bouchier C, Goldman GH, Bell-Pedersen D, GriffithsJones S, Doonan JH, Yu J, Vienken K, Pain A, Freitag M, et al: Sequencing of Aspergillus nidulans and comparative analysis with $A$. fumigatus and $A$. oryzae. Nature 2005, 438(7071):1105-1115.

58. Pel HJ, de Winde JH, Archer DB, Dyer PS, Hofmann G, Schaap PJ, Turner G, de Vries RP, Albang R, Albermann K, Andersen MR, Bendtsen JD, Benen JA, van den Berg M, Breestraat S, Caddick MX, Contreras R, Cornell M, Coutinho PM, Danchin EG, Debets AJ, Dekker P, van Dijck PW, van Dijk A, Dijkhuizen L, Driessen AJ, d'Enfert C, Geysens S, Goosen C, Groot GS, et al: Genome sequencing and analysis of the versatile cell factory Aspergillus niger CBS 513.88. Nat Biotechnol 2007, 25(2):221-231.

59. Machida M, Asai K, Sano M, Tanaka T, Kumagai T, Terai G, Kusumoto K, Arima T, Akita O, Kashiwagi Y, Abe K, Gomi K, Horiuchi H, Kitamoto K, Kobayashi T, Takeuchi M, Denning DW, Galagan JE, Nierman WC, Yu J, Archer DB, Bennett JW, Bhatnagar D, Cleveland TE, Fedorova ND, Gotoh O, Horikawa H, Hosoyama A, Ichinomiya M, Igarashi R, et al: Genome sequencing and analysis of Aspergillus oryzae. Nature 2005, 438(7071):1157-1161.

60. Sharpton TJ, Stajich JE, Rounsley SD, Gardner MJ, Wortman JR, Jordar VS, Maiti R, Kodira CD, Neafsey DE, Zeng Q, Hung CY, McMahan C, Muszewska A, Grynberg M, Mandel MA, Kellner EM, Barker BM, Galgiani JN, Orbach MJ, Kirkland TN, Cole GT, Henn MR, Birren BW, Taylor JW: Comparative genomic analyses of the human fungal pathogens Coccidioides and their relatives. Genome Res 2009, 19(10):1722-1731.

61. Cuomo CA, Guldener U, Xu JR, Trail F, Turgeon BG, Di Pietro A, Walton JD, Ma LJ, Baker SE, Rep M, Adam G, Antoniw J, Baldwin T, Calvo S, Chang YL, Decaprio D, Gale LR, Gnerre S, Goswami RS, Hammond-Kosack K, Harris L, Hilburn K, Kennell JC, Kroken S, Magnuson JK, Mannhaupt G, Mauceli E, Mewes HW, Mitterbauer R, Muehlbauer G, et al: The Fusarium graminearum genome reveals a link between localized polymorphism and pathogen specialization. Science 2007, 317(5843):1400-1402.

62. Coleman JJ, Rounsley SD, Rodriguez-Carres M, Kuo A, Wasmann CC, Grimwood J, Schmutz J, Taga M, White GJ, Zhou S, Schwartz DC, Freitag M, Ma $L$, Danchin EG, Henrissat B, Coutinho PM, Nelson DR, Straney D, Napoli CA, Barker BM, Gribskov M, Rep M, Kroken S, Molnar I, Rensing C, Kennell JC, Zamora J, Farman ML, Selker EU, Salamov A, et al: The genome of Nectria haematococca: contribution of supernumerary chromosomes to gene expansion. PLoS Genet 2009, 5(8):e1000618.

63. Dean RA, Talbot NJ, Ebbole DJ, Farman ML, Mitchell TK, Orbach MJ, Thon M, Kulkarni R, Xu JR, Pan H, Read ND, Lee YH, Carbone I, Brown D, Oh YY, Donofrio N, Jeong JS, Soanes DM, Djonovic S, Kolomiets E, Rehmeyer C, Li W, Harding M, Kim S, Lebrun MH, Bohnert H, Coughlan S, Butler J, Calvo S, Ma LJ, et al: The genome sequence of the rice blast fungus Magnaporthe grisea. Nature 2005, 434(7036):980-986.

64. Galagan JE, Calvo SE, Borkovich KA, Selker EU, Read ND, Jaffe D, FitzHugh W, Ma LJ, Smirnov S, Purcell S, Rehman B, Elkins T, Engels R, Wang S, Nielsen CB, Butler J, Endrizzi M, Qui D, lanakiev P, Bell-Pedersen D, Nelson MA, Werner-Washburne M, Selitrennikoff CP, Kinsey JA, Braun EL, Zelter A, Schulte U, Kothe GO, Jedd G, Mewes W, et al: The genome sequence of the filamentous fungus Neurospora crassa. Nature 2003, 422(6934):859-868
65. van den Berg MA, Albang R, Albermann K, Badger JH, Daran JM, Driessen AJ, Garcia-Estrada C, Fedorova ND, Harris DM, Heijne WH, Joardar V, Kiel JA, Kovalchuk A, Martin JF, Nierman WC, Nijland JG, Pronk JT, Roubos JA, van der Klei IJ, van Peij NN, Veenhuis M, von Dohren $\mathrm{H}$, Wagner C, Wortman J, Bovenberg RA: Genome sequencing and analysis of the filamentous fungus Penicillium chrysogenum. Nat Biotechnol 2008, 26(10):1161-1168.

66. Espagne E, Lespinet O, Malagnac F, Da Silva C, Jaillon O, Porcel BM, Couloux A, Aury JM, Segurens B, Poulain J, Anthouard V, Grossetete S, Khalili H, Coppin E, Dequard-Chablat M, Picard M, Contamine V, Arnaise S, Bourdais A, Berteaux-Lecellier V, Gautheret D, de Vries RP, Battaglia E, Coutinho PM, Danchin EG, Henrissat B, Khoury RE, Sainsard-Chanet A, Boivin A, Pinan-Lucarre B, et al: The genome sequence of the model ascomycete fungus Podospora anserina. Genome Biol 2008, 9(5):R77.

67. Hane JK, Lowe RG, Solomon PS, Tan KC, Schoch CL, Spatafora JW, Crous PW, Kodira C, Birren BW, Galagan JE, Torriani SF, McDonald BA, Oliver RP: Dothideomycete Plant Interactions Illuminated by Genome Sequencing and EST Analysis of the Wheat Pathogen Stagonospora nodorum. Plant Cell 2007, 19(11):3347-3368.

68. Martinez D, Berka RM, Henrissat B, Saloheimo M, Arvas M, Baker SE, Chapman J, Chertkov O, Coutinho PM, Cullen D, Danchin EG, Grigoriev IV, Harris $P$, Jackson $M$, Kubicek CP, Han CS, Ho I, Larrondo LF, de Leon AL, Magnuson JK, Merino S, Misra M, Nelson B, Putnam N, Robbertse B, Salamov AA, Schmoll M, Terry A, Thayer N, Westerholm-Parvinen A, et al: Genome sequencing and analysis of the biomass-degrading fungus Trichoderma reesei (syn. Hypocrea jecorina). Nat Biotechnol 2008, 26(5):553-560.

69. Hibbett DS, Binder M, Bischoff JF, Blackwell M, Cannon PF, Eriksson OE, Huhndorf S, James T, Kirk PM, Lucking R, Thorsten Lumbsch H, Lutzoni F, Matheny PB, McLaughlin DJ, Powell MJ, Redhead S, Schoch CL, Spatafora JW, Stalpers JA, Vilgalys R, Aime MC, Aptroot A, Bauer R, Begerow D, Benny GL, Castlebury LA, Crous PW, Dai YC, Gams W, Geiser DM, et al: A higher-level phylogenetic classification of the Fungi. Mycol Res 2007, 111(Pt 5):509-547.

70. Jones T, Federspiel NA, Chibana H, Dungan J, Kalman S, Magee BB, Newport G, Thorstenson YR, Agabian N, Magee PT, Davis RW, Scherer S: The diploid genome sequence of Candida albicans. Proc Natl Acad Sci USA 2004, 101(19):7329-7334.

71. van het Hoog M, Rast TJ, Martchenko M, Grindle S, Dignard D, Hogues H, Cuomo C, Berriman M, Scherer S, Magee BB, Whiteway M, Chibana H, Nantel A, Magee PT: Assembly of the Candida albicans genome into sixteen supercontigs aligned on the eight chromosomes. Genome Biol 2007, 8(4):R52

72. Butler G, Rasmussen MD, Lin MF, Santos MA, Sakthikumar S, Munro CA, Rheinbay E, Grabherr M, Forche A, Reedy JL, Agrafioti I, Arnaud MB, Bates S, Brown AJ, Brunke S, Costanzo MC, Fitzpatrick DA, de Groot PW, Harris D, Hoyer LL, Hube B, Klis FM, Kodira C, Lennard N, Logue ME, Martin R, Neiman AM, Nikolaou E, Quail MA, Quinn J, et al: Evolution of pathogenicity and sexual reproduction in eight Candida genomes. Nature 2009, 459(7247):657-662.

73. Dujon B, Sherman D, Fischer G, Durrens P, Casaregola S, Lafontaine I, De Montigny J, Marck C, Neuveglise C, Talla E, Goffard N, Frangeul L, Aigle M, Anthouard V, Babour A, Barbe V, Barnay S, Blanchin S, Beckerich JM, Beyne E, Bleykasten C, Boisrame A, Boyer J, Cattolico L, Confanioleri F, De Daruvar A, Despons L, Fabre E, Fairhead C, Ferry-Dumazet H, et al: Genome evolution in yeasts. Nature 2004, 430(6995):35-44.

74. Blandin G, Ozier-Kalogeropoulos O, Wincker P, Artiguenave F, Dujon B: Genomic exploration of the hemiascomycetous yeasts: 16. Candida tropicalis. FEBS Lett 2000, 487(1):91-94.

75. Dietrich FS, Voegeli S, Brachat S, Lerch A, Gates K, Steiner S, Mohr C, Pohlmann R, Luedi P, Choi S, Wing RA, Flavier A, Gaffney TD, Philippsen P: The Ashbya gossypii genome as a tool for mapping the ancient Saccharomyces cerevisiae genome. Science 2004, 304(5668):304-307.

76. Scannell DR, Frank AC, Conant GC, Byrne KP, Woolfit M, Wolfe KH: Independent sorting-out of thousands of duplicated gene pairs in two yeast species descended from a whole-genome duplication. Proc Natl Acad Sci USA 2007, 104(20):8397-8402.

77. Kellis M, Birren BW, Lander ES: Proof and evolutionary analysis of ancient genome duplication in the yeast Saccharomyces cerevisiae. Nature 2004, 428(6983):617-624. 
78. Jeffries TW, Grigoriev IV, Grimwood J, Laplaza JM, Aerts A, Salamov A, Schmutz J, Lindquist E, Dehal P, Shapiro H, Jin YS, Passoth $V$, Richardson PM: Genome sequence of the lignocellulose-bioconverting and xylose-fermenting yeast Pichia stipitis. Nat Biotechnol 2007, 25(3):319-326

79. Cliften P, Sudarsanam P, Desikan A, Fulton L, Fulton B, Majors J, Waterston $\mathrm{R}$, Cohen BA, Johnston M: Finding functional features in Saccharomyces genomes by phylogenetic footprinting. Science 2003, 301(5629):71-76.

80. Kellis M, Patterson N, Endrizzi M, Birren B, Lander ES: Sequencing and comparison of yeast species to identify genes and regulatory elements. Nature 2003, 423(6937):241-254

81. Liti G, Carter DM, Moses AM, Warringer J, Parts L, James SA, Davey RP, Roberts IN, Burt A, Koufopanou V, Tsai IJ, Bergman CM, Bensasson D, O'Kelly MJ, van Oudenaarden A, Barton DB, Bailes E, Nguyen AN, Jones M, Quail MA, Goodhead I, Sims S, Smith F, Blomberg A, Durbin R, Louis EJ: Population genomics of domestic and wild yeasts. Nature 2009, 458(7236):337-341.

82. Doniger SW, Kim HS, Swain D, Corcuera D, Williams M, Yang SP, Fay JC: A catalog of neutral and deleterious polymorphism in yeast. PLoS Genet 2008, 4(8):e1000183

83. Goffeau A, Barrell BG, Bussey H, Davis RW, Dujon B, Feldmann H, Galibert F, Hoheisel JD, Jacq C, Johnston M, Louis EJ, Mewes HW, Murakami Y, Philippsen P, Tettelin H, Oliver SG: Life with 6000 genes. Science 1996, 274(5287):563-547.

84. Gu Z, David L, Petrov D, Jones T, Davis RW, Steinmetz LM: Elevated evolutionary rates in the laboratory strain of Saccharomyces cerevisiae. Proc Natl Acad Sci USA 2005, 102(4):1092-1097.

85. Wood V, Gwilliam R, Rajandream MA, Lyne M, Lyne R, Stewart A, Sgouros J, Peat N, Hayles J, Baker S, Basham D, Bowman S, Brooks K, Brown D, Brown $S$, Chillingworth T, Churcher C, Collins M, Connor R, Cronin A, Davis P, Feltwell T, Fraser A, Gentles S, Goble A, Hamlin N, Harris D, Hidalgo J, Hodgson G, Holroyd S, et al: The genome sequence of Schizosaccharomyces pombe. Nature 2002, 415(6874):871-880.

86. Loftus BJ, Fung E, Roncaglia P, Rowley D, Amedeo P, Bruno D, Vamathevan J, Miranda M, Anderson IJ, Fraser JA, Allen JE, Bosdet IE, Brent MR, Chiu R, Doering TL, Donlin MJ, D'Souza CA, Fox DS, Grinberg V, Fu J, Fukushima M, Haas BJ, Huang JC, Janbon G, Jones SJ, Koo HL, Krzywinski MI, Kwon-Chung JK, Lengeler KB, Maiti R, et al: The genome of the basidiomycetous yeast and human pathogen Cryptococcus neoformans. Science 2005, 307(5713):1321-1324.

87. Martin F, Aerts A, Ahren D, Brun A, Danchin EG, Duchaussoy F, Gibon J, Kohler A, Lindquist E, Pereda V, Salamov A, Shapiro HJ, Wuyts J, Blaudez D, Buee M, Brokstein P, Canback B, Cohen D, Courty PE, Coutinho PM, Delaruelle C, Detter JC, Deveau A, DiFazio S, Duplessis S, Fraissinet-Tachet L, Lucic E, Frey-Klett P, Fourrey C, Feussner I, et al: The genome of Laccaria bicolor provides insights into mycorrhizal symbiosis. Nature 2008, 452(7183):88-92.

88. Martinez D, Larrondo LF, Putnam N, Gelpke MD, Huang K, Chapman J, Helfenbein KG, Ramaiya P, Detter JC, Larimer F, Coutinho PM, Henrissat B, Berka $\mathrm{R}$, Cullen D, Rokhsar D: Genome sequence of the lignocellulose degrading fungus Phanerochaete chrysosporium strain RP78. Nat Biotechnol 2004, 22(6):695-700.

89. Kamper J, Kahmann R, Bolker M, Ma LJ, Brefort T, Saville BJ, Banuett F, Kronstad JW, Gold SE, Muller O, Perlin MH, Wosten HA, de Vries R, RuizHerrera J, Reynaga-Pena CG, Snetselaar K, McCann M, Perez-Martin J, Feldbrugge M, Basse CW, Steinberg G, Ibeas II, Holloman W, Guzman P, Farman M, Stajich JE, Sentandreu R, Gonzalez-Prieto JM, Kennell JC, Molina $L$, et al: Insights from the genome of the biotrophic fungal plant pathogen Ustilago maydis. Nature 2006, 444(7115):97-101.

90. Ma L, Ibrahim AS, Skory C, Grabherr MG, Burger G, Butler M, Elias M, Idnurm A, Lang BF, Sone T, Abe A, Calvo SE, Corrochano LM, Engels R, Fu J, Hansberg W, Kim JM, Kodira CD, Koehrsen MJ, Liu B, Miranda-Saavedra D, O'Leary S, Ortiz-Castellanos L, Poulter R, Rodriguez-Romero J, Ruiz-Herrera J, Shen $Y Q$, Zeng Q, Galagan J, Birren BW, et al: Genomic analysis of the basal lineage fungus Rhizopus oryzae reveals a whole-genome duplication. PLoS Genet 2009, 5(7):e1000549.

91. Katinka MD, Duprat $S$, Cornillot E, Metenier G, Thomarat F, Prensier G, Barbe V, Peyretaillade E, Brottier P, Wincker P, Delbac F, El Alaoui H, Peyret P, Saurin W, Gouy M, Weissenbach J, Vivares CP: Genome sequence and gene compaction of the eukaryote parasite Encephalitozoon cuniculi. Nature 2001, 414(6862):450-453.

92. Gardner MJ, Hall N, Fung E, White O, Berriman M, Hyman RW, Carlton JM, Pain A, Nelson KE, Bowman S, Paulsen IT, James K, Eisen JA, Rutherford K, Salzberg SL, Craig A, Kyes S, Chan MS, Nene V, Shallom SJ, Suh B, Peterson J, Angiuoli S, Pertea M, Allen J, Selengut J, Haft D, Mather MW, Vaidya $A B$, Martin DM, et al: Genome sequence of the human malaria parasite Plasmodium falciparum. Nature 2002, 419(6906):498-511.

93. Haas BJ, Kamoun S, Zody MC, Jiang RH, Handsaker RE, Cano LM, Grabherr M, Kodira CD, Raffaele S, Torto-Alalibo T, Bozkurt TO, Ah-Fong AM, Alvarado L, Anderson VL, Armstrong MR, Avrova A, Baxter L, Beynon J, Boevink PC, Bollmann SR, Bos Jl, Bulone V, Cai G, Cakir C, Carrington JC, Chawner M, Conti L, Costanzo S, Ewan R, Fahlgren N, et al: Genome sequence and analysis of the Irish potato famine pathogen Phytophthora infestans. Nature 2009, 461(7262):393-398.

94. Tyler BM, Tripathy S, Zhang X, Dehal P, Jiang RH, Aerts A, Arredondo FD, Baxter L, Bensasson D, Beynon JL, Chapman J, Damasceno CM, Dorrance AE, Dou D, Dickerman AW, Dubchak IL, Garbelotto M, Gijzen M, Gordon SG, Govers F, Grunwald NJ, Huang W, Ivors KL, Jones RW, Kamoun S, Krampis K, Lamour KH, Lee MK, McDonald WH, Medina M, et al: Phytophthora genome sequences uncover evolutionary origins and mechanisms of pathogenesis. Science 2006, 313(5791):1261-1266.

doi:10.1186/1471-2164-11-105

Cite this article as: Choi et al:: Fungal Secretome Database: Integrated platform for annotation of fungal secretomes. BMC Genomics 2010 11:105.

\section{Submit your next manuscript to BioMed Central and take full advantage of:}

- Convenient online submission

- Thorough peer review

- No space constraints or color figure charges

- Immediate publication on acceptance

- Inclusion in PubMed, CAS, Scopus and Google Scholar

- Research which is freely available for redistribution

Submit your manuscript at www.biomedcentral.com/submit
C) Biomed Central 